
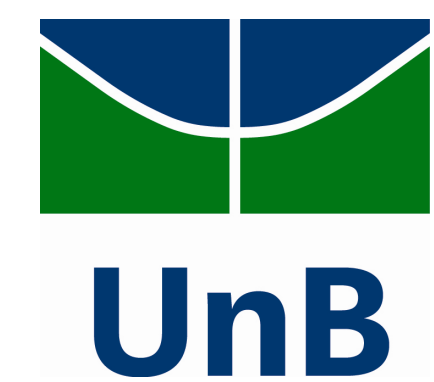

Universidade de Brasília

Faculdade de Economia, Administração, Contabilidade e Ciência da Informação e Documentação (FACE)

Departamento de Ciência da Informação e Documentação

KELLY PEREIRA MARQUES RUTHLÉA ELIENNAI DIAS DO NASCIMENTO

\title{
INDEXAÇÃO DE IMAGENS FOTOGRÁFICAS DE ACERVO PESSOAL EM MEIO DIGITAL
}


KELLY PEREIRA MARQUES RUTHLÉA ELIENNAI DIAS DO NASCIMENTO

\title{
INDEXAÇÃO DE IMAGENS FOTOGRÁFICAS DE ACERVO PESSOAL EM MEIO DIGITAL
}

\author{
Monografia apresentada ao \\ Departamento de Ciência da \\ Informação e Documentação \\ como requisito para a obtenção \\ do título de bacharel em \\ Biblioteconomia \\ Orientadora: Profa. Miriam Paula \\ Manini
}


$\mathrm{N} 244 \mathrm{i}$

Nascimento, Ruthléa Eliennai Dias do Indexação de imagens de acervo pessoal em meio digital / Ruthléa Eliennai Dias do Nascimento e Kelly Pereira Marques. - Brasília, 2009. 59 p. : Il.

Monografia (Graduação) - Universidade de Brasília, Departamento de Ciência da Informação e Documentação, 2009.

Orientadora: Prof $^{\mathrm{a}} \mathrm{Dr}^{\mathrm{a}}$ Miriam Paula Manini

1. Indexação de imagens. 2. Acervo pessoal. 3. Ambiente digital. 4. Folksonomia. I. Marques, Kelly Pereira. II. Título 
UNIVERSIDADE DE BRASILIA (UnB)

Faculdade de Economia, Administração, Contabilidade e Ciência da Informação e Documentação (FACE)

Departamento de Ciência da Informação e Documentação (CID)

Título: INDEXAÇÃO DE IMAGENS FOTOGRÁFICAS DE ACESSO PESSOAL EM MEIO DIGITAL.

Alunas: Kelly Pereira Marques e Ruthlea Elienai Dias do Nascimento.

Monografia apresentada ao Departamento de Ciência da Informação e Documentação da Universidade de Brasília, como parte dos requisitos para obtenção do grau de Bacharel em Biblioteconomia.

Brasilia, 07 de dezembro de 2009.

Aprovada por:

Mirian Paula Manini - Orientadora

Professora do Departamento de Ciência da Informação e Documentação (UnB)

Doutora em Ciências da Comunicação

$$
\text { Marisa Brascher Basílio Medeiros-Membro }
$$

Professora do Departamento de Ciência da Informaçăo e Documentaçăo (UnB)

Doutora em Ciência da Informação

\section{Lutte Kalare \\ Ivette Kafure Muñoz - Membro}

Professora do Departamento de Ciência da Informação e Documentação

Doutora em Ciência da Informação

Edificio da Biblioteca Central (BCE) - Entrada Leste - Campus Universitário Darcy Ribeiro - Asa Norte - Brasilia, DF CEP 70910-900 - Tel.: +55 (61) 3307-2422 - Fax: +55 (61) 3273-8454-E-mall: cid@unbbr $30 / 11 / 2009$ 15:30:19 


\section{DEDICATÓRIA}

Às nossas mães, por seu amor e apoio incondicional. 


\section{AGRADECIMENTOS}

São muitas as pessoas que nos marcaram em todos esses anos de vida e de UnB também. Algumas, no entanto merecem especial deferência de nossa parte:

Professora Miriam Paula Manini, nossa orientadora, pelo apoio inestimável à esse trabalho, por sanar nossas dúvidas de forma simples e rápida.

Tânia Cristina de Oliveira, nossa amiga, por revisar a monografia para nós e nos aturar nos momentos de histeria (e compartilhar do sentimento) causados por esse trabalho.

\section{Kelly}

"Agradeço a Deus, em primeiro lugar, por tudo o que Ele tem realizado em minha vida. Agradeço à minha mãe e heroína, Terezinha, por não me deixar desanimar nos momentos difíceis e me confortar. Também agradeço à minha irmã, Kamila, por tornar a fase de monografia mais divertida, me distraindo, me fazendo rir e me aturando.

Aos amigos por todo apoio.

E à amiga e colega de monografia, Ruth, por tornar o processo de execução do trabalho menos árduo e mais divertido."

Em memória de Maria Zeferina, uma pessoa muito querida que cuidou de mim."

\section{Ruthléa}

"Agradeço em primeiro lugar a Deus, que tem me abençoado muito, permitindo entre outras coisas, que eu chegasse até aqui. Agradeço à minha mãe, Carmelita, por ser a melhor mãe do mundo, não me deixar parar na hora do cansaço e me mostrar "a luz no fim do túnel" mesmo quando tudo parece perdido.

Ao meu pai, Edmilson, por ser um pai maravilhoso e à minha tia Elenita, pelo apoio.

À minha amiga Kelly, por compartilhar comigo essa jornada, dividindo o fardo e tornado-o até agradável para ser sincera.

À minha pinscher Kitty, minha chihuahua Bibi e minha vira-lata Mila, por serem fontes constantes de alegria e me ajudarem a relaxar durante a execução desse trabalho." 
"É a fotografia um intrigante documento visual cujo conteúdo é a um só tempo revelador de informações e detonador de emoções."

Boris Kossoy. 


\section{RESUMO}

O presente trabalho apresenta uma proposta de indexação para imagens fotográficas de acervos pessoais de usuários leigos. Para tal, baseia-se nos modelos de indexação de imagens de Erwin Panofsky, Corinne Jörgensen e Sara Shatford e estuda as características da folksonomia. A metodologia utilizada é pesquisa bibliográfica e para melhor embasar o estudo, define-se o conceito de fotografia e sua diferenciação de imagem fotográfica. Realiza-se um breve estudo histórico desde a imagem até a fotografia digital. Explanam-se as possibilidades de uso da fotografia a partir das reflexões de Phillipe Dubois, Jean-Marie Schaeffer e Miriam Manini. Faz uma abordagem da imagem fotográfica no acervo pessoal, e levanta questões a respeito da manipulação de imagens. Conclui fazendo uma análise dos modelos vistos na pesquisa bibliográfica e recomendando o que pode ser mais útil para o usuário doméstico.

Palavras-chave: Indexação, Imagem fotográfica, Acervos pessoais, Fotografia, Folksonomia 


\begin{abstract}
This assignment presents a suggestion on photographic images indexing in personal collections of layman users. For such, the assignment is based on the image indexing models of Erwin Panofsky, Corinne Jörgensen and Sara Shatford, and it studies the characteristics of folksonomy. The methodology used is the bibliographic research. In order to provide a better understanding and foundation for this study, the concept of photography is defined and its differentiation from photographic image is explained. A brief historic study from the age of image to the age of digital photography is also performed. The possibilities of the use of photography are explored, based on the reflections made by Philippe Dubois, Jean-Marie Schaeffer and Miriam Manini. The photographic image in the personal collection is approached, raising questions concerning the image manipulation. The study is concluded by making an analysis of the indexing models that were cited in the bibliographic research and by a recommendation of what can be more useful to the domestic user.
\end{abstract}

Keywords: Indexing, Photographic image, Personal collection, Photography, Folksonomy 


\section{LISTA DE ILUSTRAÇÕES}

Figura 1 - Vista da janela em Les Gras/Nicéphore Niépce p. 19

Figura 2 - A conquista da honra/Joe Rosenthal p.22

Figura 3- Ruthléa e Kelly - Acervo pessoal p. 23

Figura 4 - Ruthléa e Kelly - Acervo pessoal p. 23

Figura 5 - "A ponte japonesa", de Claude Monet p. 27

Figura 6 - Japanese bridge at Giverny p. 28

Figura 7 - Imagem capturada do DVD filme "Closer - perto demais" p. 31

Figura 8 - Imagem capturada do DVD filme "Closer - perto demais" p. 31

Figura 9 - Imagem capturada do DVD do filme "Orgulho e preconceito" p. 33

Figura 10 - Imagem capturada do DVD do filme "Orgulho e preconceito" p. 33

Figura 11 - Imagem capturada do DVD do filme "Orgulho e preconceito" p. 34

Figura 12 - Imagem capturada do DVD do filme "Orgulho e preconceito" p. 34

Figura 13 - Mila / Ruthléa Nascimento - Acervo pessoal p. 43

Figura 14 - Lembranças da UnB/Acervo pessoal p. 45

Figura 15 - "Mrs. Siddons as the Tragic Muse", de Joshua Reynolds p. 46

Figura 16 - "A primavera", de Botticelli p. 48

Figura 17 - Kitty / Ruthléa Nascimento - Acervo pessoal p. 50

Figura 18 - Página do Flickr. p. 51

Figura 19 - Página de busca do Flickr p. 52

Figura 20 - Página do Flickr. p. 53

Figura 21 - Gustavo/ Kelly Marques - Acervo pessoal p. 55

Figura 22 - Janela de navegação da Galeria de imagem do Windows Vista® Home Premium. p. 56 


\section{Sumário}

1 INTRODUÇÃO

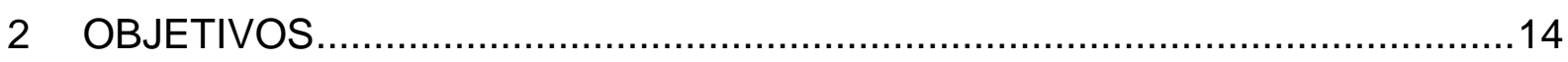

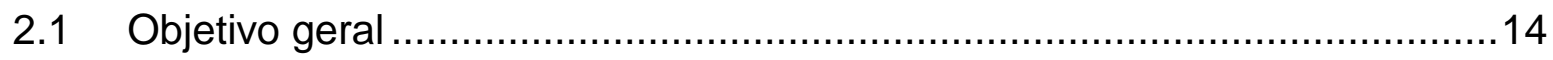

2.2 Objetivos específicos .......................................................................

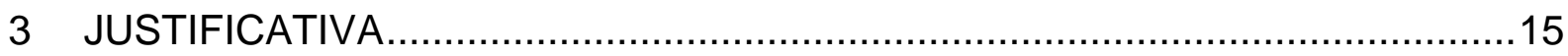

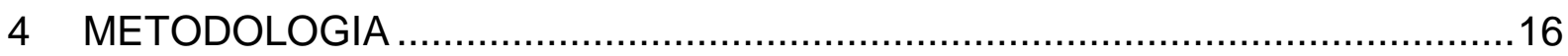

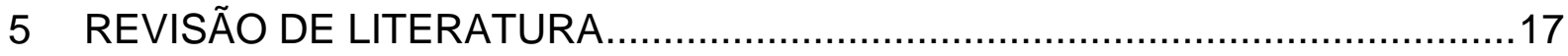

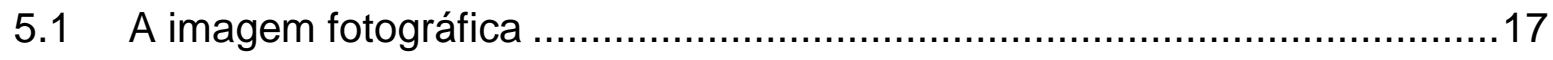

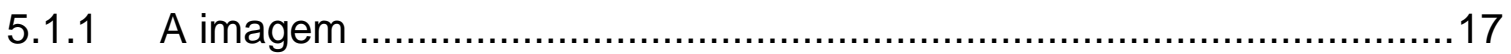

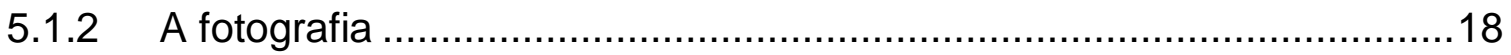

5.1.3 Fotografia digital, imagem fotográfica e manipulação da realidade .......20

5.1.4 Possibilidades de uso da fotografia ................................................24

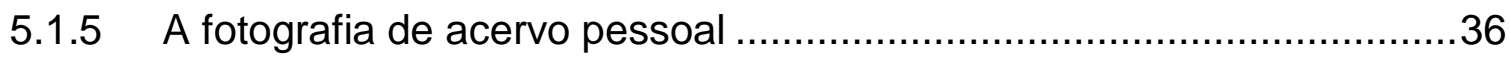

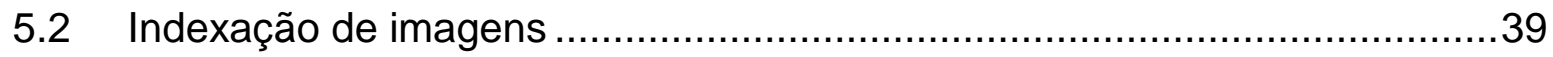

5.2.1 Indexação com base em conceitos................................................... 40

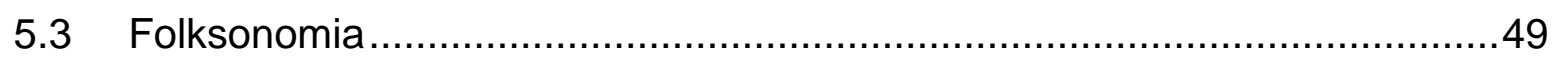

6 A FOLKSONOMIA NA INDEXAÇÃO DE IMAGENS FOTOGRÁFICAS DE

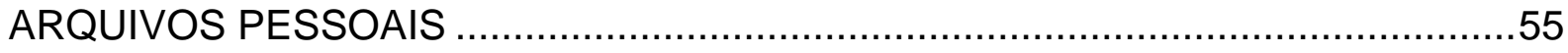

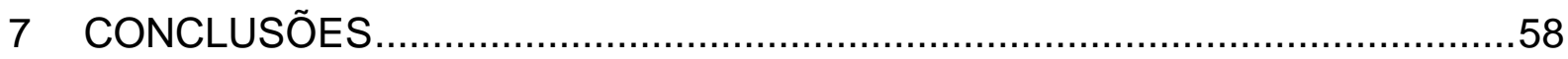

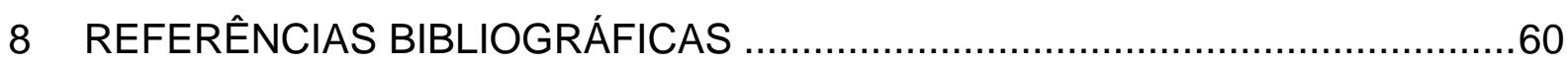

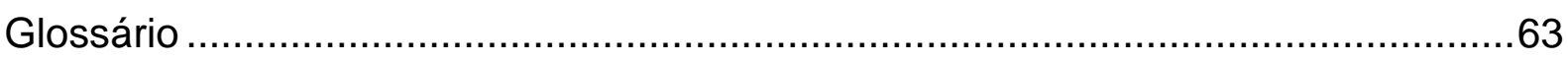




\section{INTRODUÇÃO}

As imagens sempre exerceram grande importância na história da humanidade. Foram a primeira forma de registro informacional, bem antes do surgimento da escrita. Sendo inicialmente algo prático, com o passar do tempo foram se sofisticando cada vez mais e sua utilidade se ampliando. Das cavernas às câmeras digitais foi um longo percurso.

Atualmente, a produção de informação é enorme. Estima-se que o volume informacional dobra a cada sete minutos ${ }^{1}$. Com as novas tecnologias, grande parte das pessoas passa a ser também consumidora e, ao mesmo tempo, produtora de informação. As imagens fazem parte dessa revolução. Basta observar o sucesso que redes sociais como Flickr® e Picasa ${ }^{\circledR}$ fazem. Isso sem contar os álbuns no Orkut ${ }^{\circledR}$, Facebook $\AA$, entre outros. Com o advento das câmeras digitais, cada vez mais modernas, acessíveis e simples, todos somos fotógrafos.

Eis então que, com essa "explosão imagética", chega-se a problema semelhante ao causado pela explosão informacional em meados dos anos 1950: como organizar essas imagens de arquivos pessoais de forma a permitir uma recuperação precisa?

Aumont (1995, apud Lopes, 2006, p. 202) afirma que “(..) o problema do sentido da imagem é, pois, o da relação entre imagem e palavras, entre imagem e linguagem e que para ser compreendida, uma imagem necessita do domínio da linguagem verbal.".

A afirmativa de Amount, juntamente com as anteriores, leva-nos a indagar: como esse usuário leigo de informação - aqui considerado como o produtorconsumidor da informação e que organiza suas informações, utilizando critérios próprios e, geralmente, subjetivos - poderá fazer a relação entre imagens e palavras da qual fala a autora, se dificilmente conta com um profissional da informação para

\footnotetext{
${ }^{1}$ Informação verbal fornecida por André Siqueira, doutorando em Ciência da Informação, na disciplina "Seminário em Biblioteconomia - Arquitetura da Informação", em 28/8/2009.
} 
auxiliá-lo? Sabe-se que ele organiza individualmente seu arquivo de imagens fotográficas, geralmente usando o que a literatura científica chama de folksonomia. Seu significado será visto no decorrer deste trabalho, mas é, essencialmente, neste trabalho, uma maneira de indexar informações utilizando linguagem natural. 


\section{OBJETIVOS}

\section{$2.1 \quad$ Objetivo geral}

Encontrar um modelo de indexação de imagens presente na literatura que possa ser aplicado pelo usuário leigo na organização de seu arquivo pessoal de imagens.

\subsection{Objetivos específicos}

Identificar na literatura os modelos de indexação de imagens com base em conceitos;

Baseando-se na literatura, definir folksonomia e abordar suas vantagens e desvantagens;

Fazer uma breve abordagem histórica da imagem fotográfica, delineando suas possibilidades de uso e questionamentos éticos que envolvem as novas tecnologias. 


\section{JUSTIFICATIVA}

O volume informacional vem crescendo rapidamente e o usuário se tornou também produtor de informação (usuário leigo). Por ser ele mesmo o responsável por organizar seus próprios arquivos, faz-se necessário definir diretrizes para auxiliar esse usuário leigo a organizar de forma clara a informação que produz e/ou consome. 


\section{METODOLOGIA}

Optou-se neste trabalho de conclusão de curso por realizar uma revisão de literatura teórica, método que melhor atende aos objetivos definidos. A base do trabalho foram os estudos de Miranda (2007), Lancaster (2004) e Manini (2002), que oferecem uma visão geral sobre o assunto abordado. 


\section{REVISÃo DE LITERATURA}

A revisão de literatura do presente trabalho irá abordar os seguintes tópicos: acervos pessoais, histórico da imagem fotográfica e indexação de imagens. Apesar de não estar intimamente relacionado ao tema, achou-se por bem fazer uma revisão sobre o histórico da imagem fotográfica para dar um maior embasamento à pesquisa.

\subsection{A imagem fotográfica}

\subsubsection{A imagem}

O dicionário Houaiss (2008) define imagem como sendo a "representação, reprodução ou imitação da forma de uma pessoa ou objeto". Para Cavalcanti e Cunha (2008, p. 190), imagem é a "representação bidimensional de um ou de vários objetos ou formas. Trata-se de um tipo de documento icônico". Apesar das diferenças entre os conceitos, ambos têm em comum um ponto: a imagem simplesmente como representação. Por isso, recorreu-se também à semiótica ${ }^{2}$; Greimas e Courtés (1979) definem imagem como "uma unidade de manifestação auto-suficiente, como um todo de significação, capaz de ser submetida à análise".

Marcondes (2005) afirma que, desde o tempo das cavernas, a imagem é utilizada como forma de registro. De acordo com Smit (1996), o termo imagem,

\footnotetext{
${ }^{2}$ Semiótica é a ciência geral dos signos, que estuda todos os fenômenos culturais como se fossem sistemas sígnicos, isto é, sistemas de significação. Ocupa-se do estudo do processo de significação ou representação, na natureza e na cultura, do conceito ou da ideia. Esta ciência tem por objeto qualquer sistema sígnico.
} 
propriamente dito, "abrange um leque de documentos iconográficos ou de ilustrações, incluindo pinturas, gravuras, posters, cartões postais, fotografias, etc.".

\subsubsection{A fotografia}

Cavalcanti e Cunha (2008, p. 175) definem fotografia como "técnica ou arte de produzir imagens visíveis pela ação da luz, que fixa essas imagens de modo direto e durável sobre uma superfície sensibilizada". Jean-Marie Schaeffer (1996, p. 16) diz que fotografia é "o fluxo fotônico emitido ou refletido pelo impregnante", sendo esse fluxo fotônico um canal de informação.

Foi a câmera escura, conhecida desde o século XVI, que levou à câmera fotográfica. O objeto era uma "caixa com apenas um orifício por onde os raios luminosos penetravam e projetavam a imagem no interior da caixa sobre uma superfície branca e oposta a esse orifício" (MARCONDES, 2005, p. 2). Todavia, tanto a câmera escura quanto a câmera fotográfica tinham como grande problema a efemeridade das imagens por elas produzidas e um grande desafio para os pesquisadores da época era tentar fixá-las (MARCONDES, 2005).

Assim, a fotografia surgiu no contexto da Revolução Industrial, época de grandes transformações no âmbito econômico, social e cultural. Segundo Kossoy (2001, p. 25), a invenção da fotografia naquele contexto seria "uma possibilidade inovadora de informação e conhecimento, instrumento de apoio à pesquisa nos diferentes campos da ciência e também como forma de expressão artística". Todavia, Marcondes lembra que a fotografia só se popularizou quando houve a possibilidade de reprodução imagem. Em 1826, o francês Joseph Nicéphore Nièpce obteve a imagem que se consagrou como a origem da fotografia (Figura 1), mas 0 termo fotografia só foi cunhado anos mais tarde por Hércules Florence (MARCONDES, 2005), que descobriu sozinho o processo de gravação através da luz, em 1832, antes de Jacques Louis Mandé Daguerre. Mas foi Daguerre que 
acabou levando a fama de inventor da fotografia, após publicar sua invenção, o Daguerreótipo, em 1839.

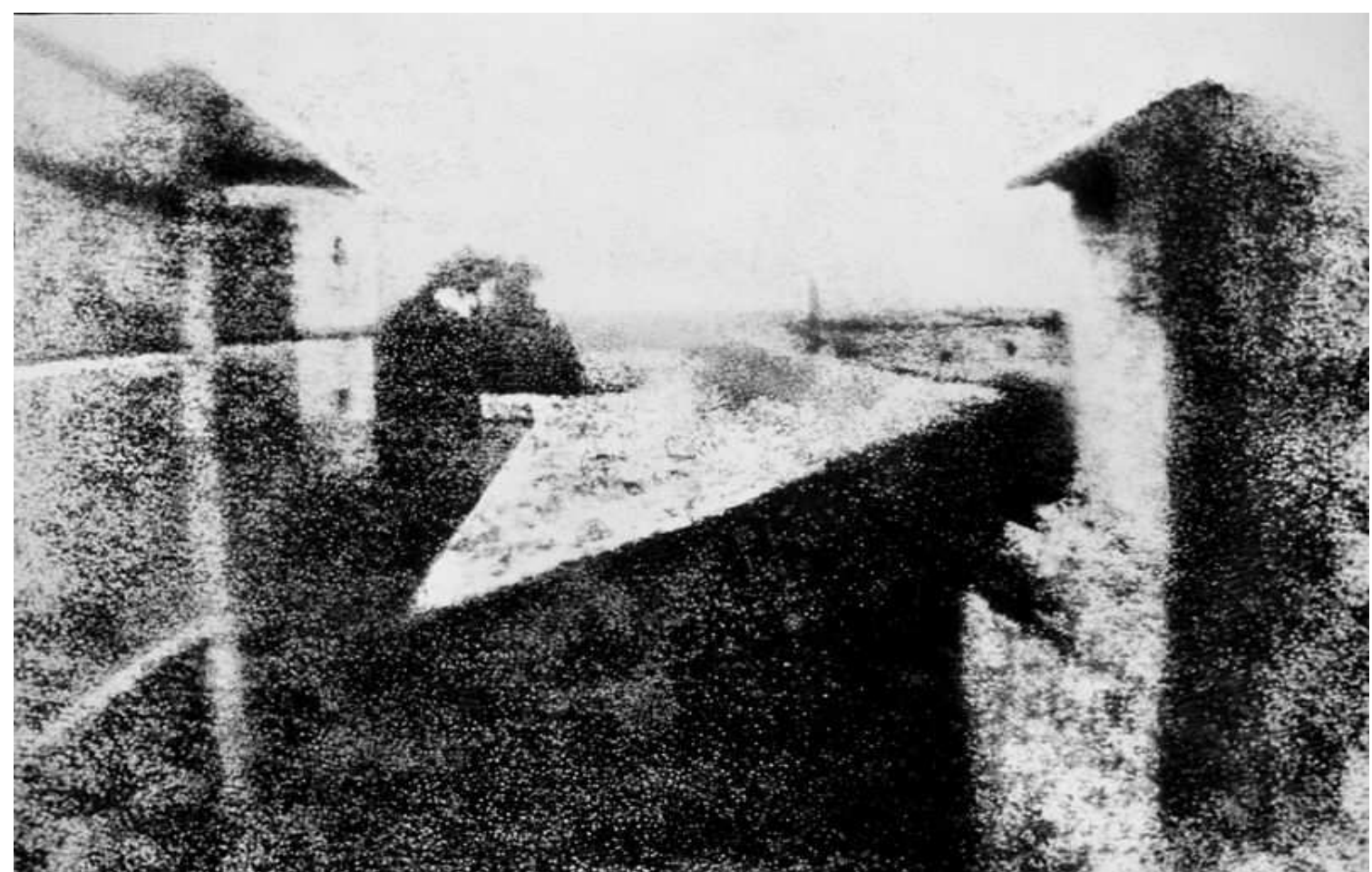

Figura 1 - Vista da janela em Les Gras/Nicéphore Niépce. Fonte: <http://pt.wikipedia.org/wiki/Ficheiro:View_from_the_Window_at_Le_Gras,_Joseph_Nic\%C3\% A9phore_Ni\%C3\%A9pce.jpg $>$. Acesso em: 16/11/2009.

De acordo com Simionato (2009), a utilização da fotografia em grande escala pela imprensa mundial para realizar grandes reportagens fotográficas despertou nos fabricantes o interesse de investir mais no setor. Talvez esse grande interesse da imprensa pela fotografia possa ser explicado por Kossoy, quando afirma que:

Microaspectos do mundo passaram a ser cada vez mais conhecidos através de sua representação. O mundo, a partir da alvorada do século $X X$, se viu (sic), aos poucos, substituído por sua imagem fotográfica. $O$ mundo tornouse, assim, portátil e ilustrado. (KOSSOY, 2001, p. 27)

Outro motivo da rápida popularização da fotografia é apresentado por Manini (2002, p. 67). A autora afirma que "a fotografia é mais fácil de ler que a palavra, no sentido em que ela imita, representa ou copia as atitudes e o gestual próprio do ser humano". 
Assim, enquanto as palavras representam por convenção, a imagem o faz por projeção. Para compreender as palavras, faz-se necessário um treinamento, um estudo do alfabeto. Em se tratando de imagens, mesmo bebês conseguem fazer associações entre imagem e objeto.

Foi tão intenso e rápido o interesse pela fotografia no século XX, que Abbott chegou a prever o fim da palavra escrita:

\begin{abstract}
O mundo hoje está condicionado, irresistivelmente, a visualizar. A imagem quase substituiu a palavra como meio de comunicação. Tablóides, filmes educativos e documentais, películas de massa, revistas e televisão rodeiamnos (sic). Parece até que a existência da palavra está ameaçada. A imagem é um dos principais meios de interpretação, e sua importância está se tornando cada vez maior. (ABBOTT, 1951, apud FABRIS, 2007, p. 1)
\end{abstract}

Abbott foi infeliz ao cogitar o fim da existência da palavra, mas é inegável a importância da imagem (e mais ainda da fotografia) na atualidade. Na busca por métodos cada vez melhores e mais simples de tirar fotografias, no final da década de 1980 surgiu a fotografia digital.

\title{
5.1.3 Fotografia digital, imagem fotográfica e manipulação da realidade
}

A fotografia digital surgiu como uma evolução da fotografia analógica. Uma diferença entre ela e sua antecessora é que ela é armazenada em arquivos digitais ao passo que a fotografia analógica é armazenada em filmes fotográficos. Claro que as diferenças não param por aí.

A fotografia digital trouxe possibilidades impensáveis para a fotografia analógica. É possível ver como a fotografia vai ficar antes mesmo de tirá-la e, se o resultado não for o almejado, é só apagar e tirar outra fotografia. A fotografia digital dá a possibilidade de manipular com facilidade o registro do momento. Com ela ouve uma mudança de paradigma. A fotografia deixou de ser um simples registro para se tornar uma construção, aproximando-se da pintura. Por causa desse distanciamento 
da fotografia analógica (ou fotografia tradicional), especialistas têm sugerido que seja usado o termo imagem fotográfica para diferenciar a fotografia digital de sua antecessora ${ }^{3}$.

Simionato (2009) lembra que a evolução dos aparatos digitais contribuiu para o desaparecimento gradual da fotografia analógica e para sua transformação em objeto primitivo. A tecnologia e seus avanços fizeram com que o mundo se tornasse mais receptível ao mundo digital e o que se tem hoje é o uso dessa tecnologia, em massa. Todavia, é cedo para afirmar que a fotografia analógica irá desaparecer. Isso porque o grupo de apaixonados por essa técnica ainda é grande. A fotografia analógica é mais "romântica", dado o nível de técnica e habilidade que exige. Amantes da fotografia analógica reclamam da imagem fotográfica por sua facilidade de manipulação e, de fato, a imagem fotográfica tem suscitado inúmeros questionamentos a respeito de sua veracidade e o principal é: até que ponto é possível confiar no que vemos numa imagem fotográfica? Os defensores da fotografia analógica afirmam que não é possível saber se o que a imagem fotográfica representa é real ou não. Defensores da imagem fotográfica rebatem, citando casos famosos de manipulação da fotografia analógica.

Um caso famoso de manipulação é a fotografia "A conquista da honra", do fotógrafo americano Joe Rosenthal (Figura 2).

\footnotetext{
${ }^{3}$ Informação verbal dada por Miriam Manini no "Seminário Aberto do Grupo de Pesquisa Imagem, Memória e Informação", Brasília, 11/11/2009.
} 


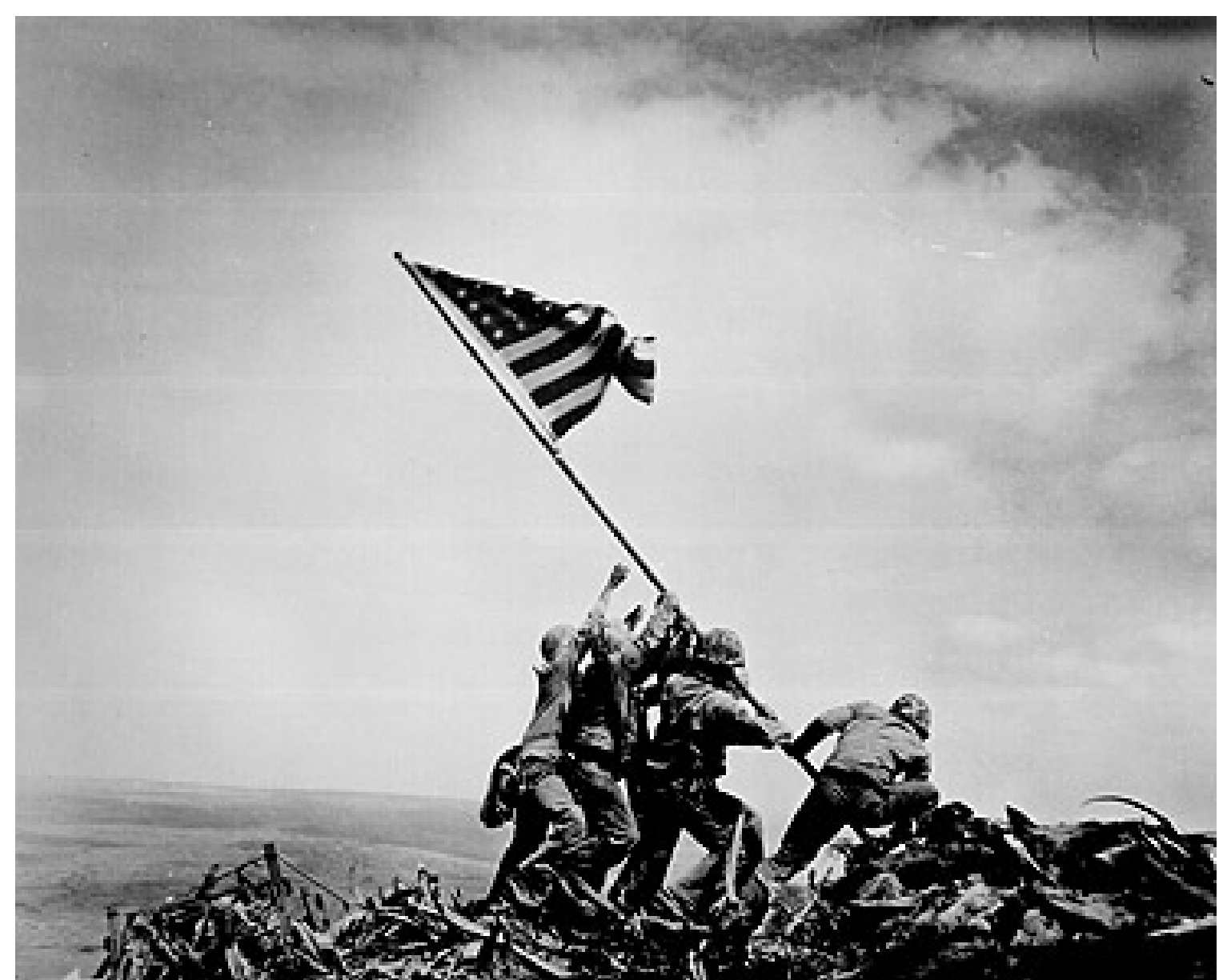

Figura 2 - A conquista da honra/Joe Rosenthal. Disponível em:

$<$ http://www.comunicacaoeinternet2.jex.com.br/includes/imagem.php?id_jornal=9150\&id_notici a=92>. Acesso em: 19/11/2009.

Tirada em 1945, durante a II Guerra Mundial, a fotografia mostra seis fuzileiros navais americanos hasteando a bandeira de seu país no monte Suribachi, após a conquista da ilha de Iwo Jima, no Japão. Vemos a bandeira americana tremulando ao vento e o esforço dos homens para erguer o símbolo de seu país. Rosenthal ganhou o prêmio Pulitzer e a fotografia chegou a ser considerada "a foto do Século XX", e uma das mais poderosas imagens de propaganda de guerra no período. Qual não foi então a surpresa ao se descobrir que Rosenthal chegou atrasado ao monte Suribachi, quando a bandeira já tinha sido hasteada, e pediu aos soldados que repetissem o gesto várias vezes para que ele fotografasse.

No caso da fotografia de Rosenthal não ouve manipulação na técnica fotográfica. Ele não precisou recorrer a alterações químicas nem a nada parecido; no entanto, houve manipulação da realidade quando ele pediu que o gesto fosse repetido. O patriotismo retratado na fotografia não é autêntico (já que, como já foi 
dito, a cena foi repetida várias vezes). A fotografia de Rosenthal, mesmo analógica, não pode ser considerada como um testemunho.

A manipulação da realidade nas imagens pode acontecer em qualquer circunstancia, independente da técnica fotográfica empregada. A diferença é que a imagem fotográfica permite que isso seja feito de forma rápida e simples, depois de tirada a fotografia, mesmo por quem não tem conhecimentos avançados de fotografia ou softwares de edição de imagens. Tem-se um exemplo na Figura 3:

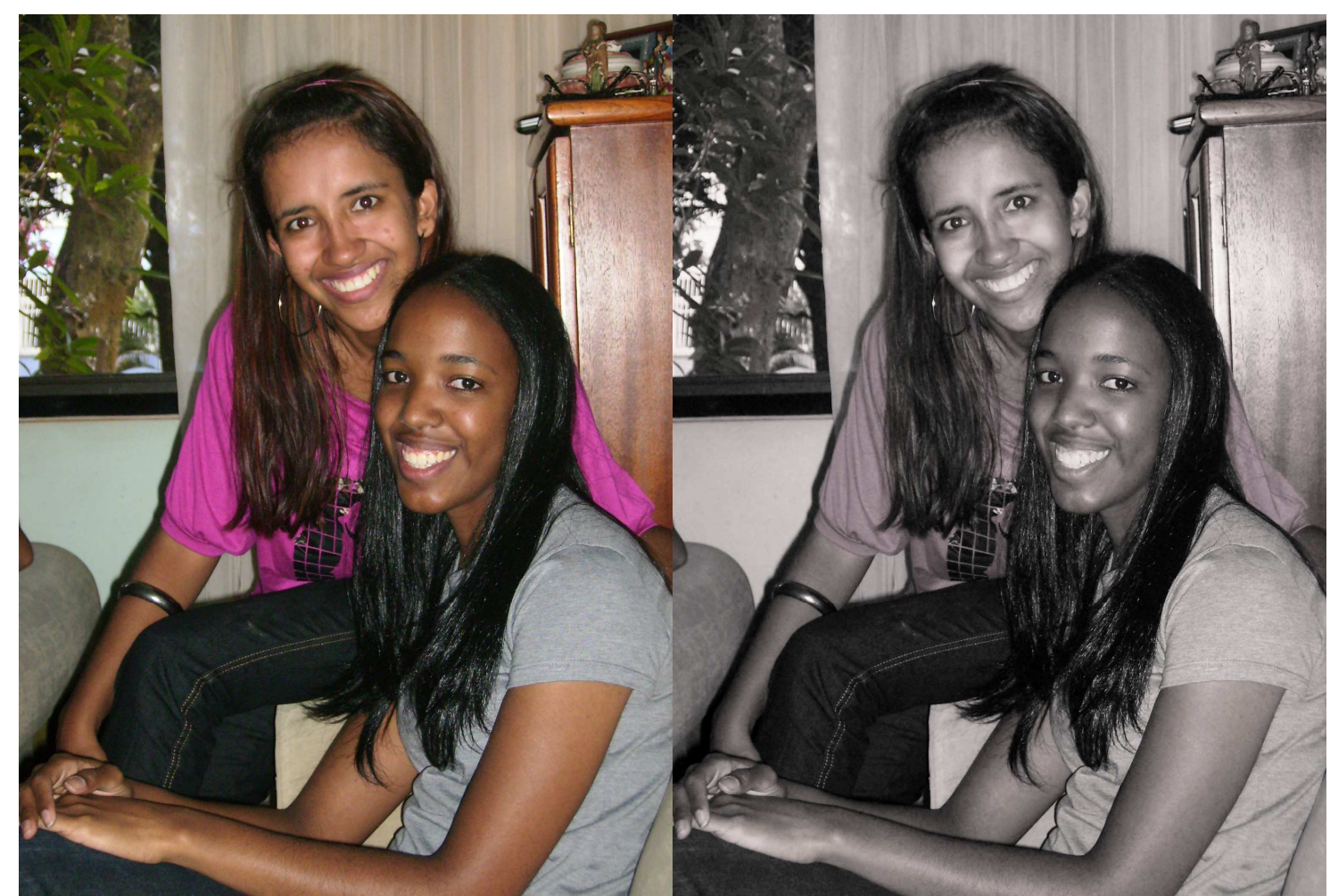

Figura 3 23- Ruthléa e Kelly - Acervo pessoal. pessoal.

Figura 4 - Ruthléa e Kelly - Acervo

A imagem fotográfica à esquerda é a original, tirada durante uma reunião de amigos. À direita, vê-se a mesma imagem fotográfica, mas alterada com o auxílio do software de edição de imagens Photoshop ${ }^{\circledR}$. Retirou-se a cor da imagem fotográfica e manchas de espinha do rosto da jovem de blusa rosa à esquerda, Ruthléa. Obteve-se uma imagem diferente, que não corresponde à realidade das duas jovens naquele contexto. Supondo-se que a primeira imagem fotográfica fosse destruída: futuramente, um interpretante que não conhecesse Ruthléa teria uma imagem dela 
que não corresponderia à realidade dela, assim como o mundo teve em relação à fotografia "A conquista da honra".

Ambas as fotografias foram alteradas com uma finalidade e é interessante no estudo da fotografia conhecer suas possibilidades de uso.

\subsubsection{Possibilidades de uso da fotografia}

A imagem é a representação de algo e a fotografia uma forma de fazer essa representação. Mas para que representar algo, desenvolver técnicas para fixar essa representação? Por que e para que representar? Buscando responder a essas perguntas, vejamos a seguir as "respostas" de Phillipe Dubois, Jean-Marie Schaeffer e Miriam Manini.

\subsubsection{Phillipe Dubois}

O uso da fotografia foi investigado por Phillipe Dubois, que, baseando-se também na semiótica e nos conceitos definidos por Peirce ${ }^{4}$, definiu três grandes momentos ${ }^{5}$ de uso e percepção da fotografia:

\footnotetext{
${ }^{4}$ Charles Sanders Peirce (1839-1914): químico, matemático, físico e astrônomo americano. Foi o criador da Semiótica.

${ }^{5}$ Momento, aqui, refere-se a fases; todavia, essas fases não se contrapõem. O surgimento de uma não leva ao fim das anteriores, ou seja, "momentos" (ou fases) é apenas uma maneira de melhor delimitar os fatos.
} 


\subsection{Fotografia como ícone ou espelho do real}

Essa fase ocorreu no século XIX, quando a fotografia era vista como uma reprodução fiel da realidade. Peirce (2008, p. 64) define ícone como "qualquer coisa que é capaz de ser um substituto para qualquer coisa com a qual se assemelhe" e afirma que "a única maneira de se comunicar uma idéia diretamente é através do ícone". Ícone é representação por excelência. A Wikipédia, no verbete "ícone", cita como exemplo um retrato que se toma pela pessoa retratada.

Dubois (2008) relata que, na época do discurso da fotografia como "a imitação mais perfeita da realidade", início do século XIX, houve quem enxergasse a fotografia como uma expressão artística. Assim como houve quem desprezasse qualquer tipo de associação entre fotografia e arte. Baudelaire ${ }^{6}$ foi um dos que se opuseram a aceitar a fotografia como expressão de arte, pois, para ele, arte era associada à pintura, e a fotografia estava associada à indústria.

É portanto necessário que ela volte ao seu verdadeiro dever, que é o de servir ciências e artes, mas de maneira bem humilde, como a tipografia e a estenografia $^{7}$, que não criaram nem substituíram a literatura (BAUDELAIRE apud DUBOIS, 2008, p. 29).

Pode-se perceber, no trecho acima, o temor de que a fotografia viesse a ocupar por completo o mundo das artes. Ainda de acordo com Dubois, Baudelaire dizia que a foto não poderia ser ao mesmo tempo arte e documento, pois a arte é uma forma de fuga da realidade.

Mas existiram também discursos totalmente favoráveis à fotografia, inclusive de pintores, como, por exemplo, Picasso:

\footnotetext{
${ }^{6}$ Charles Baudelaire, Le public moderne et la fotografia, 1999.

${ }^{7}$ Também conhecida como taquigrafia, "(do grego taqui = rápido e grafia = escrita) é um termo geral que define todo método abreviado ou simbólico de escrita, com o objetivo de melhorar a velocidade da escrita ou a brevidade, em comparação a um método padrão de escrita" (WIKIPEDIA). Acesso em 26/11/2009.
} 
Quando você vê tudo o que é possível exprimir através da fotografia, descobre que o que não pode ficar por mais tempo no horizonte da representação pictorial. Por que o artista continuaria a tratar de sujeitos que podem ser obtidos com tanta precisão pela objetividade de um aparelho de fotografia? [...] A fotografia chegou no momento certo para libertar a pintura de qualquer anedota, de qualquer literatura e até do sujeito. Em todo caso, um certo aspecto do sujeito hoje depende do campo da fotografia (DUBOIS, 2008, p. 31).

Dubois cita ainda que muitos retratistas oficiais acabaram se tornando fotógrafos profissionais. Isto mostra que dificilmente a fotografia poderia substituir a pintura e vice-versa. Ambas têm uma função particular na vida das pessoas, seja como fuga ou enfrentamento da realidade e não deveriam ser comparadas. Como exemplo, apresenta-se as Figuras 4 e 5, que são representações diferentes de um mesmo lugar: o jardim japonês da casa do pintor francês Claude Monet, em Giverny, na França. A diferença é que uma imagem é a pintura feita pelo próprio Monet e a outra é uma imagem fotográfica. 


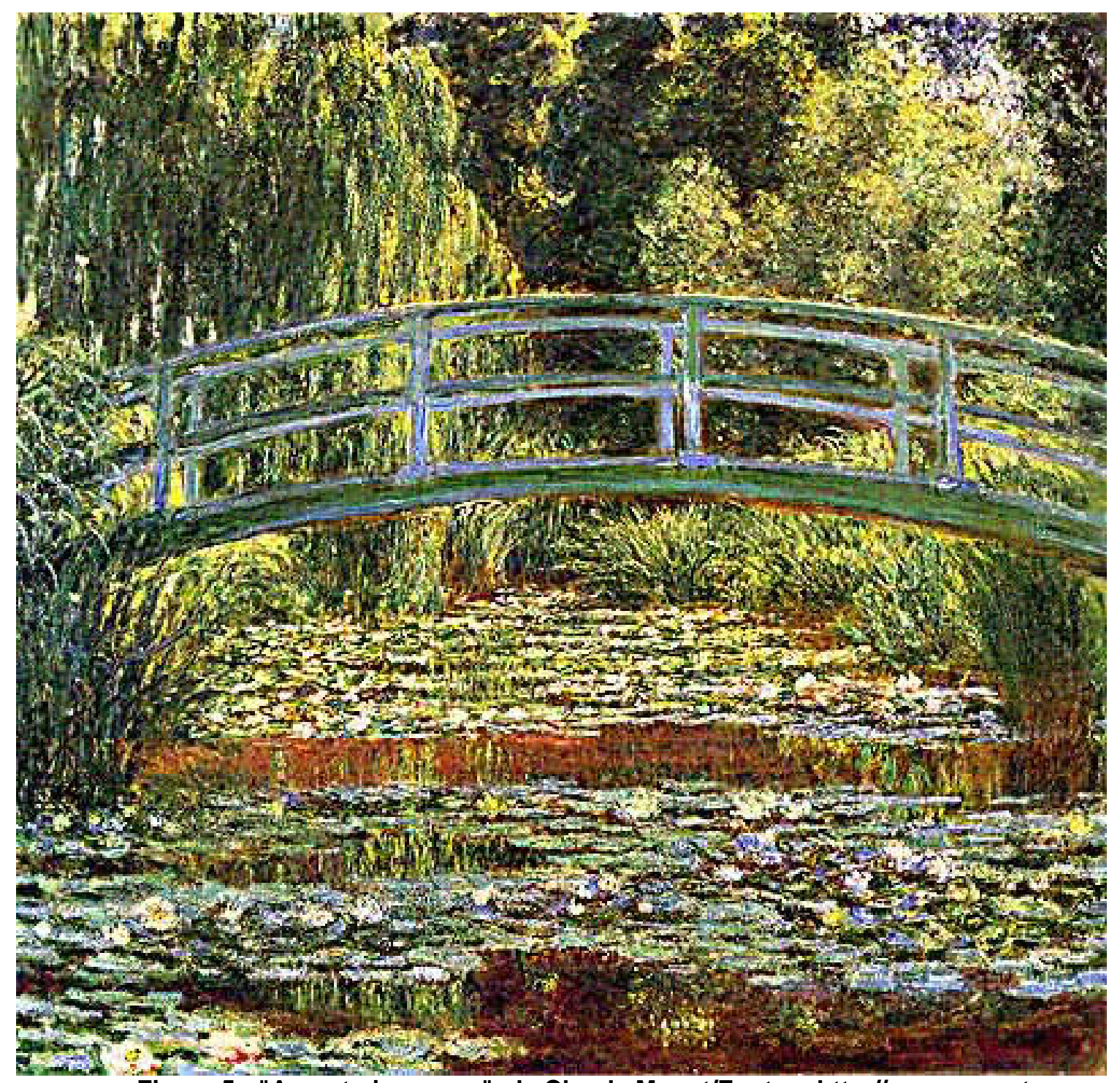

Figura 5 - "A ponte japonesa", de Claude Monet/Fonte: <http://www.monet-oncanvas.com/images/bassin_aux_nympheas_99_monet_17.jpg>. Acesso em: 19/11/2009. 


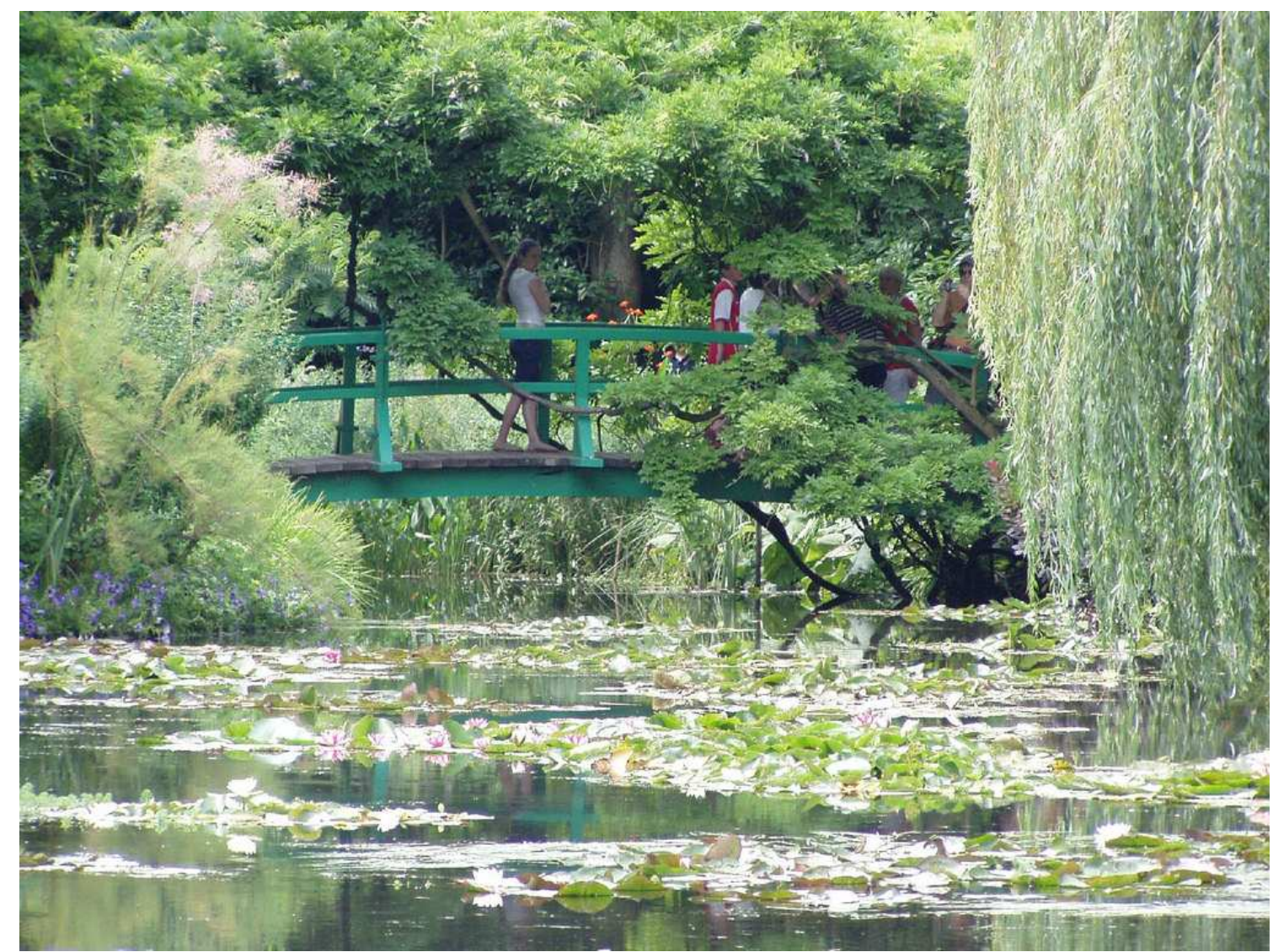

Figura 6 - Japanese bridge at Giverny/Fonte:

<http://www.flickr.com/photos/68777787@N00/204704210/>. Acesso em: 19/11/2009.

\subsection{Fotografia como símbolo ou transformação do real}

A fotografia torna-se uma representação relativa da realidade, após sofrer uma leitura cultural e ideológica. Na definição peirceana, símbolo é "alguma coisa que representa algo para alguém".

Ainda sobre a segunda fase da fotografia, Dubois (2008) relata que o discurso de sua desconstrução foi mais forte no século XX. A fotografia foi vista como uma transformação da realidade por causa da sua incapacidade de representar perfeitamente o real.

Citando os escritos de Rudolf Arnheim, o autor destaca algumas diferenças entre a imagem fotográfica e o real: os ângulos, que são escolhidos, o contraste 
entre as cores, a dimensionalidade e o fato de não conseguir transmitir outros efeitos perceptivos, como o olfato e o tato; ou seja, o que se tem é apenas uma visão parcial da realidade.

Dubois (2008) também coloca que o significado das imagens fotográficas é determinado culturalmente, reforçando, assim, o uso antropológico das fotografias. E afirma que, para que a leitura dessas imagens seja feita de forma correta, faz-se necessário "um aprendizado dos códigos de leitura" (DUBOIS, 2008, p. 42). Como exemplo, cita um relato de Alan Sekulla, no artigo On the invention of photographic meaning, em que o antropólogo Melville Herskövitz mostra a fotografia de seu filho a uma aborígine. Esta foi incapaz de reconhecer a foto, até que o antropólogo the mostrasse os detalhes da imagem e lhe explicitasse os códigos que a compunham.

De acordo com o pensamento de Dubois, a fotografia desloca sua atenção da realidade à mensagem, incluindo aqui o trabalho, a codificação envolvida, especialmente no plano artístico. Neste plano, segundo o autor, a fotografia revela uma "verdade interior", que não é empírica. Para exemplificar, é citada a forma de retratar da fotógrafa Diane Arbus:

\begin{abstract}
Contra a imagem capturada, Arbus joga a imagem convocada e construída. Contra a espontaneidade, a pose. É por meio da imagem "plástica" que querem dar de si mesmas e que a artista as leva a produzir que se revela a "verdade", a "autenticidade" das personagens de Arbus. Eis o deslocamento: a interiorização do realismo pela transcendência do próprio código (DUBOIS, 2008, p. 43).
\end{abstract}

Dubois afirma que, na fotografia como transformação do real, existe a dicotomia entre a realidade aparente e a realidade interna, que remonta ao mito da caverna, de Platão.

O mito ${ }^{8}$ apresenta uma caverna, separada do mundo exterior por um muro bem alto. Dentro dela há um grupo de homens, quem nasceram e cresceram ali dentro. Há um feixe de luz, que entra por uma fresta da caverna. Porque estão acorrentados de costas para a entrada, os dois homens estão impossibilitados de se mexerem. A única visão que tem são sombras de outros homens e de objetos que eles transportam, que estão além do muro e mantêm uma fogueira acesa.

\footnotetext{
${ }^{8}$ Wikipedia. Acesso em: 28/11/2009.
} 
Os prisioneiros crêem que as sombras são a realidade. Se um deles for liberto, o que acontecerá? Primeiro, ele ficaria confuso pela exposição à luz, até que se acostumasse. Depois que conseguisse distinguir os objetos à sua volta, acharia que estava vendo uma sombra daqueles objetos que ele via na parede da caverna. Passado algum tempo, ele finalmente entenderia que estava diante da realidade e que, o que ele via na caverna era apenas sombra do real.

O homem, então, voltaria à caverna e tentaria contar o que viu e libertar seus companheiros. Mas eles não acreditariam e poderiam até tentar matá-lo, caso ele insistisse em sua visão do mundo exterior. Platão explica que nós somos como os prisioneiros. O mundo em que acredita-se ser o real é apenas uma sombra. $O$ mundo real, que é o das idéias, alcança-se não pelo senso comum, mas pela contemplação.

Ou seja, na fotografia como traço do real, aquilo que se vê é apenas "sombra" do real. Faz-se necessário um esforço maior para que a realidade por trás da sombra possa ser vista. O interpretante que visualiza a imagem deve ser capaz de ler nas entrelinhas, a verdadeira mensagem da imagem e não a intenção do autor.

Para fazer um paralelo com a afirmação acima, foi transcrito um trecho do filme Closer - perto demais (NICHOLS, 2004):

LARRY: Estou falando sério. O que você acha?

ALICE: É uma mentira. É um bando de estranhos tristes lindamente fotografados, e todos os ricaços babacas que apreciam arte dizem que é lindo, porque isto é o que eles querem ver. Mas as pessoas nas fotos estão tristes, e sozinhas, mas as fotos fazem o mundo parecer belo. Então a exposição é reconfortante, o que faz dela uma mentira, e todos amam uma grande mentira.

O contexto do diálogo é uma exposição, intitulada "Estranhos", em que a fotógrafa utilizou como modelos pessoas desconhecidas e supostamente tristes, como diz a personagem (o filme não mostra a exposição inteiramente). Ou seja, o trecho revela exatamente o que foi tratado anteriormente: os estranhos em questão estão tristes, mas foram fotografados de tal maneira que se obteve um efeito além do esperado - tristeza retratada de forma bela - segundo a personagem. Na Figura 7, tem-se uma das cenas, em que se mostra uma parte da exposição, onde se pode ver a fotografia da própria Alice, que chora: 


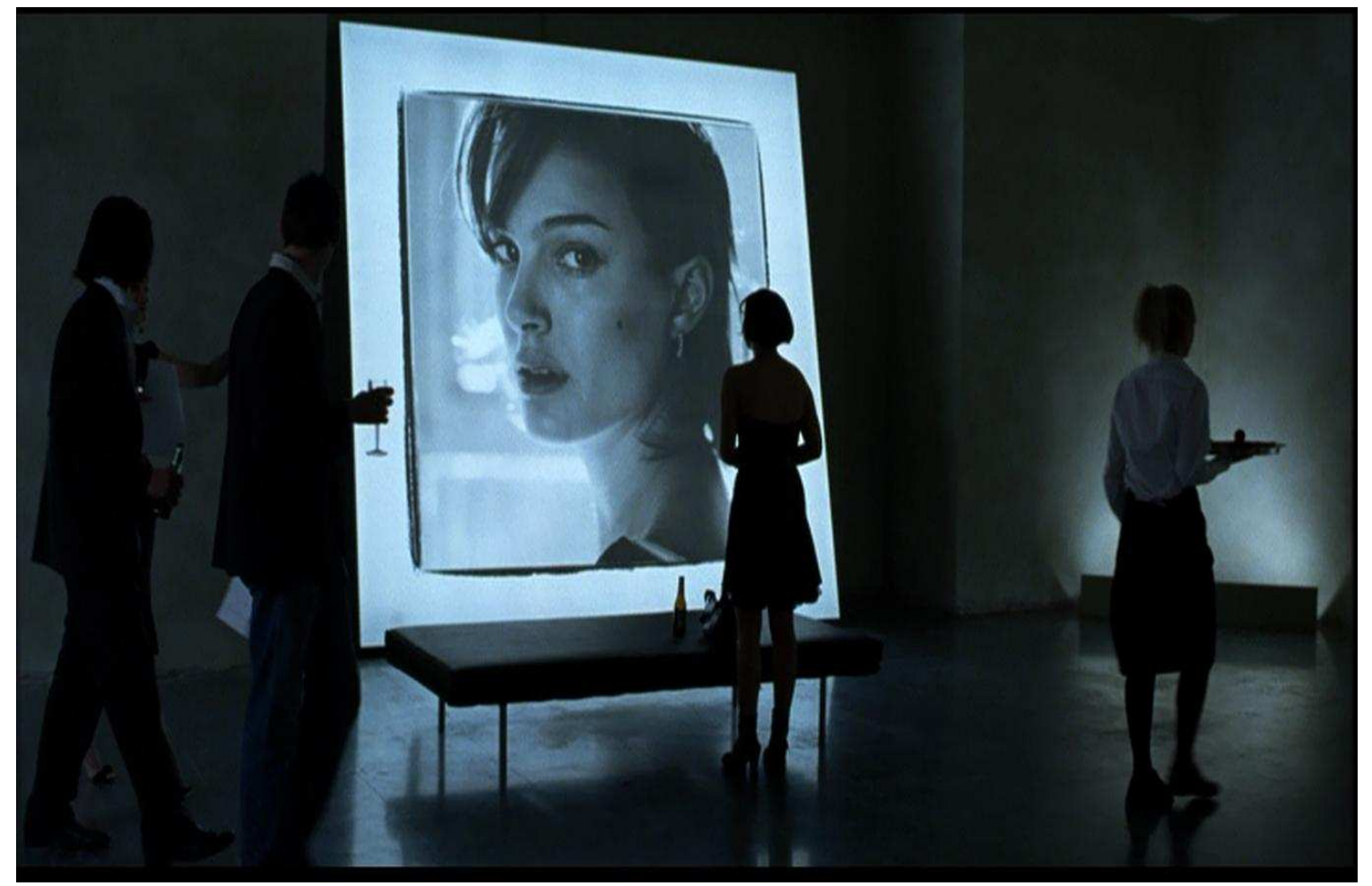

Figura 7 - Imagem capturada do DVD filme "Closer - perto demais".

A Figura 8 apresenta o contexto em que a fotografia foi tirada:

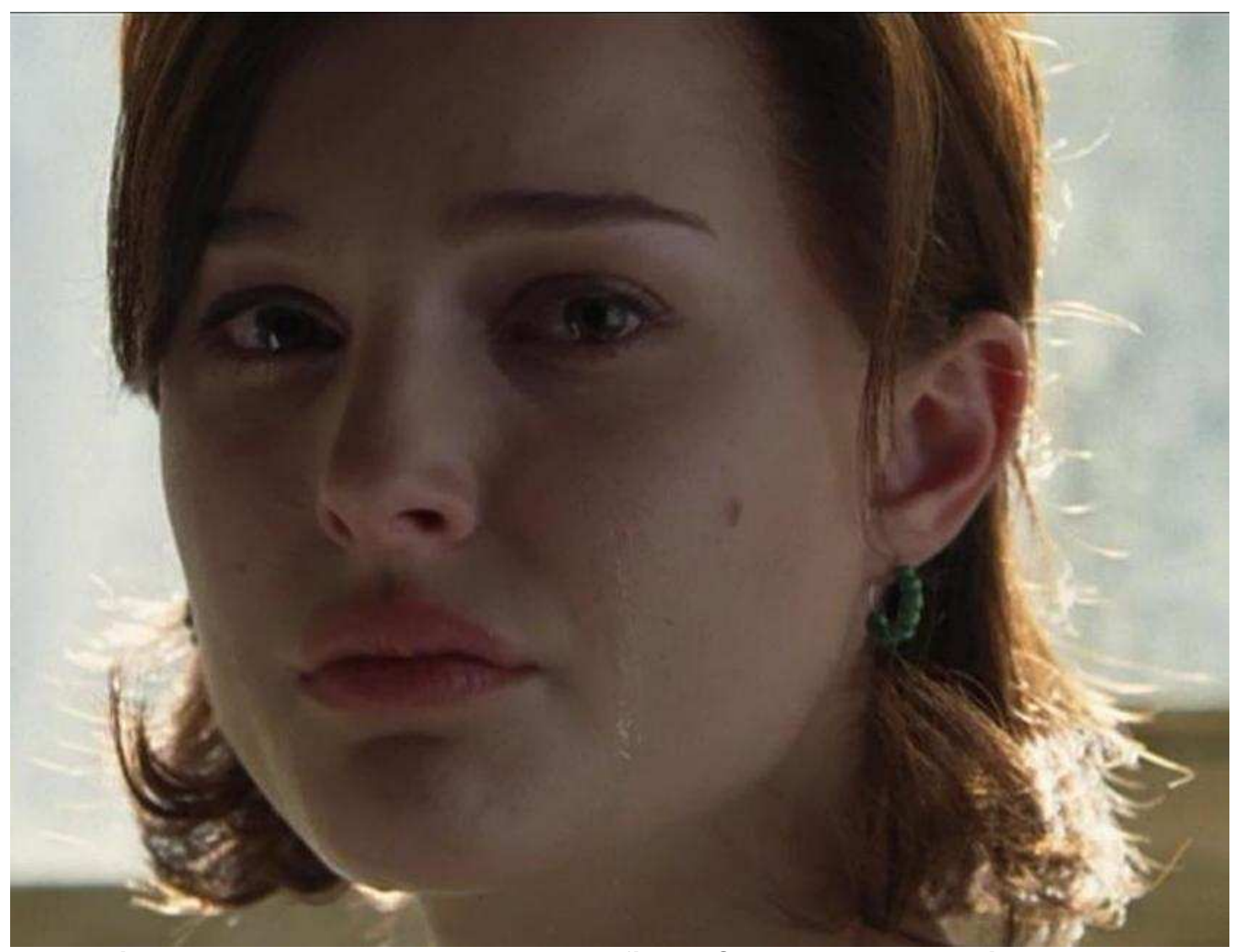

Figura 8 - Imagem capturada do DVD filme "Closer - perto demais". 


\subsection{Fotografia como traço do real}

A fotografia continua remetendo ao referente, mas sem a obrigação de ser uma representação da realidade, incorporando a relatividade cultural da percepção da imagem. Ela se torna um traço da realidade, não uma representação desta, sendo interpretada, não mais aceita como verdade absoluta. É a fotografia como índice, o qual é definido por Peirce como:

[...] um signo [...] que se refere a seu objeto não tanto em virtude de uma similaridade ou analogia qualquer com ele, nem pelo fato de estar associado a caracteres gerais que esse objeto acontece ter, mas sim por estar numa conexão dinâmica (espacial, inclusive) tanto com o objeto individual, por um lado, quanto, por outro lado, com os sentidos ou a memória da pessoa a quem serve de signo. (PEIRCE, 2008, p. 74)

Dubois afirma que:

[...] a lógica do índice que hoje assinalamos no centro da mensagem fotográfica utiliza plenamente a distinção entre sentido e existência: a fotoíndice afirma a nossos olhos a existência do que ela representa (o "isso foi", de Barthes), mas nada nos diz sobre o sentido dessa representação; ela não nos diz "isso quer dizer aquilo"(DUBOIS, 2008, p. 52).

Em outras palavras, o autor quer diz que a significação da foto permanece desconhecida, a não ser que aquele que visualiza a imagem tenha sido participante do contexto no qual ela foi feita.

Como exemplo, é apresentada uma série de imagens, as quais se tornam difíceis de interpretar sem que haja a explicação do acontecido e do contexto.

A sequência foi capturada do DVD do filme "Orgulho e Preconceito" (Wright, 2005). A cena em questão mostra Sr. Darcy auxiliando Elizabeth Bennet a descer da charrete (Figura 9). O que chamou a atenção nesta cena foi a reação que Darcy teve após tocar a mão de Elizabeth, mostrada na Figura 12. Não fica claro o que ele realmente sentiu, mas a sequência permite ver que foi uma reação mútua, mostrada

\footnotetext{
${ }^{9}$ Significa a "representação de um tempo vivido (do sentido) e não de um tempo cronológico, linear, físico e empírico" (LIMA, 2004, p. 2).
} 
tanto pelo olhar de Elizabeth (Figura 11) e pelo rápido olhar de Darcy (Figura 10), seguido do movimento que ele faz com a mão (Figura 12).

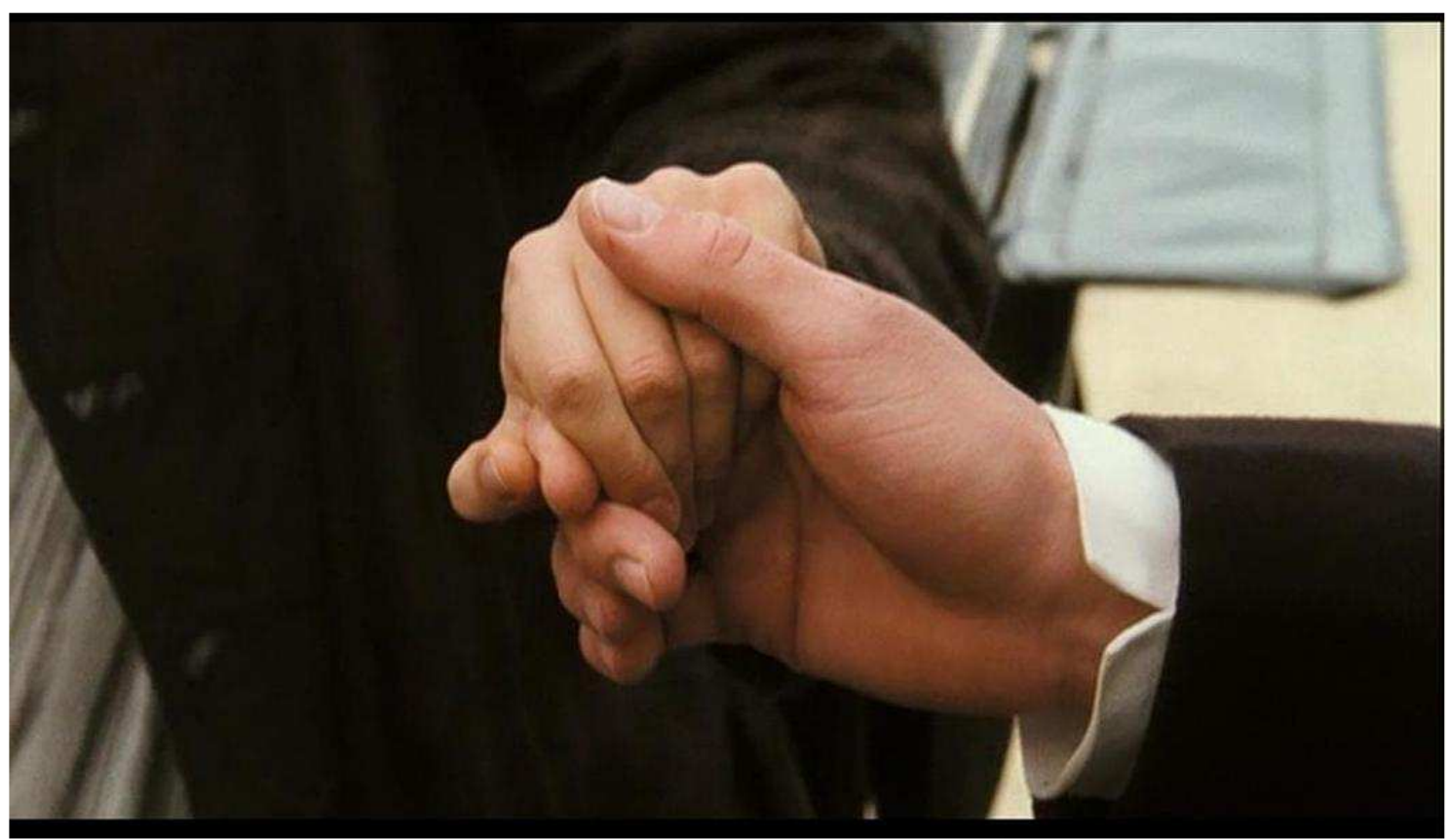

Figura 9 - Imagem capturada do DVD do filme "Orgulho e preconceito".

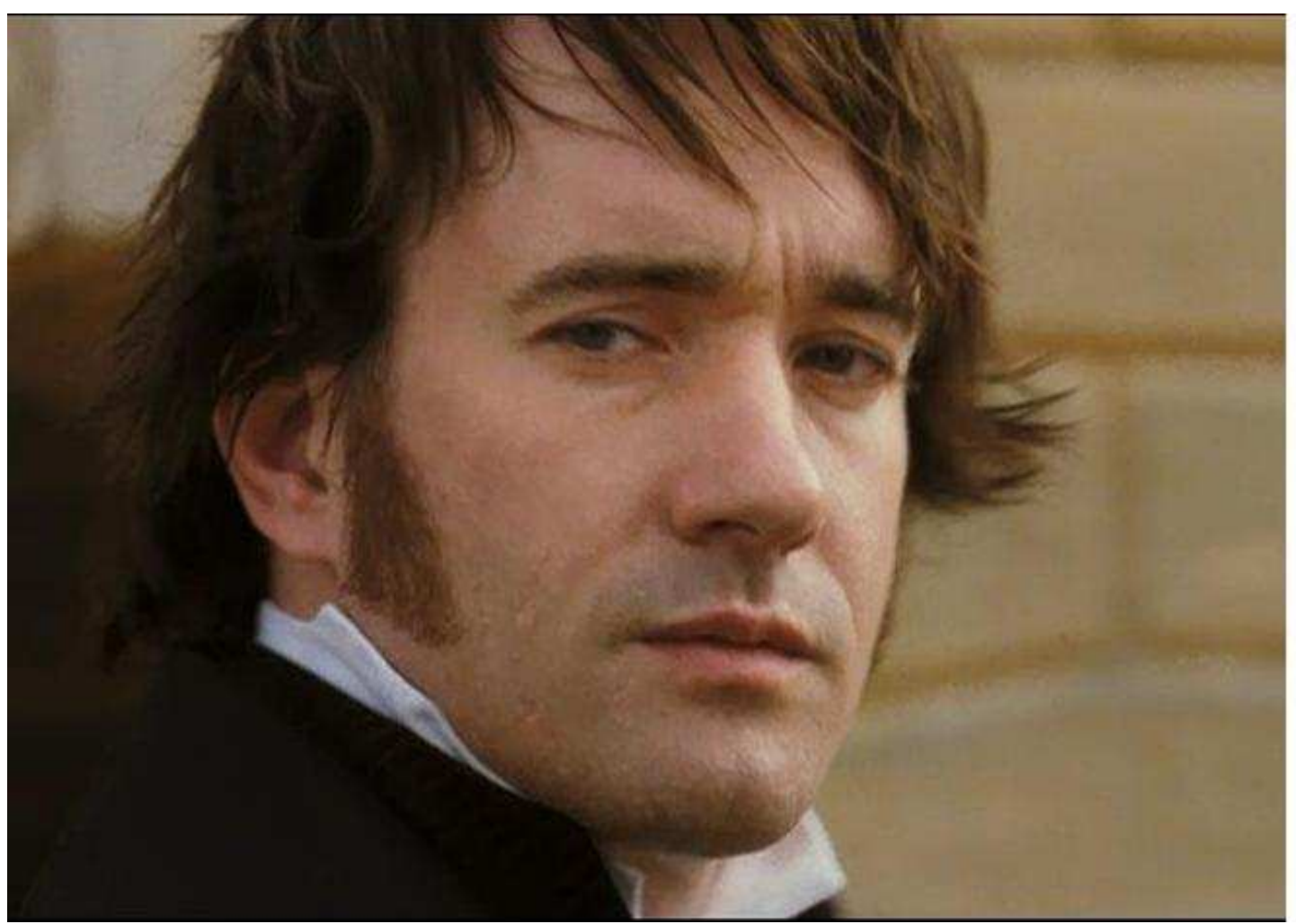

Figura 10 - Imagem capturada do DVD do filme "Orgulho e preconceito". 


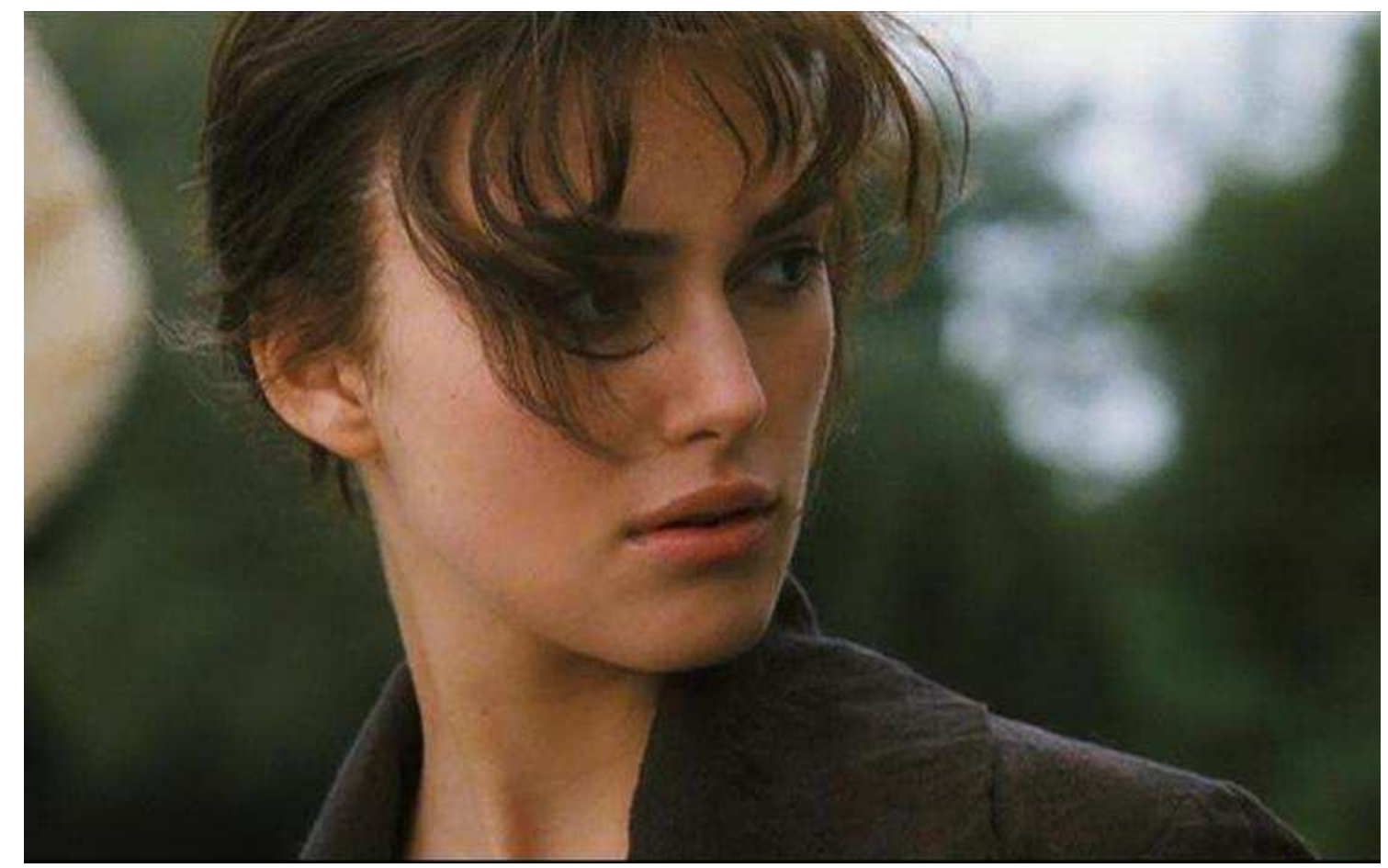

Figura 11 - Imagem capturada do DVD do filme "Orgulho e preconceito".

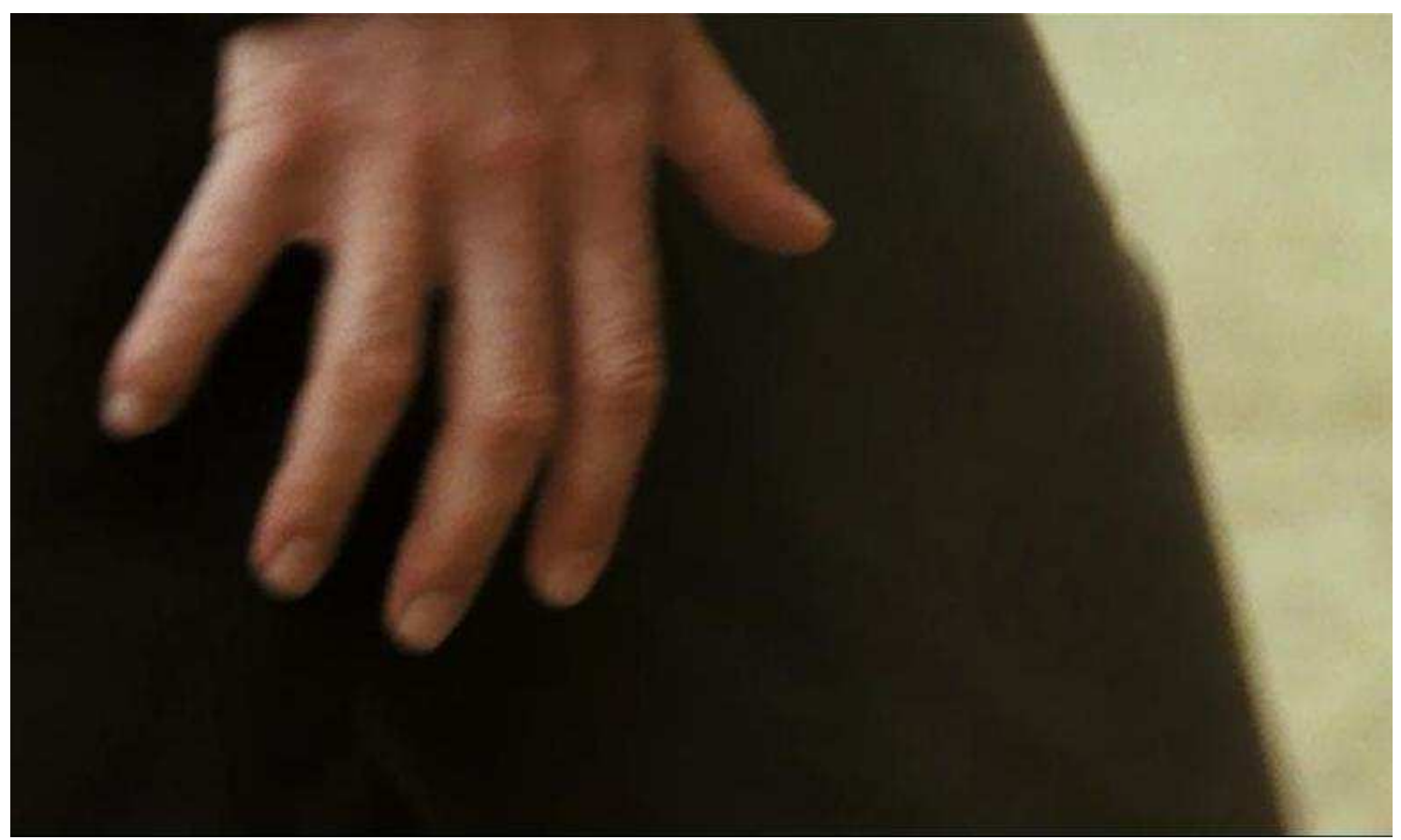

Figura 12 - Imagem capturada do DVD do filme "Orgulho e preconceito".

Se a Figura 12 fosse entregue a uma pessoa, sem qualquer informação adicional, provavelmente essa pessoa ficaria um tanto desorientada sobre o que a imagem representa. Ou seja, apenas o envolvido ou responsável por capturar a última figura têm conhecimento sobre o contexto dessa imagem. 


\subsubsection{Jean-Marie Schaeffer e Miriam Manini}

Tal como Dubois, Jean-Marie Schaeffer, em seu livro A imagem precária (1996), também trata das funções da fotografia e também se baseia nos conceitos da Semiótica desenvolvidos por Charles S. Peirce, afirmando que, para compreender as funções da fotografia, é preciso primeiro compreender a distinção e a relação entre representamen, interpretante e objeto, sendo que representamen é sinônimo de signo e definido por Peirce (apud Schaeffer, 1996, p. 48) como "qualquer coisa que ocupa o lugar, para qualquer um, de qualquer coisa em qualquer relação ou sob qualquer título [...] ocupa o lugar de alguma coisa: de seu objeto". Representamen é a representação visual do objeto.

Buscando compreender a relação entre representamen, interpretante e objeto, Schaeffer desenvolveu um quadro no qual se vê as possibilidades de uso da fotografia.

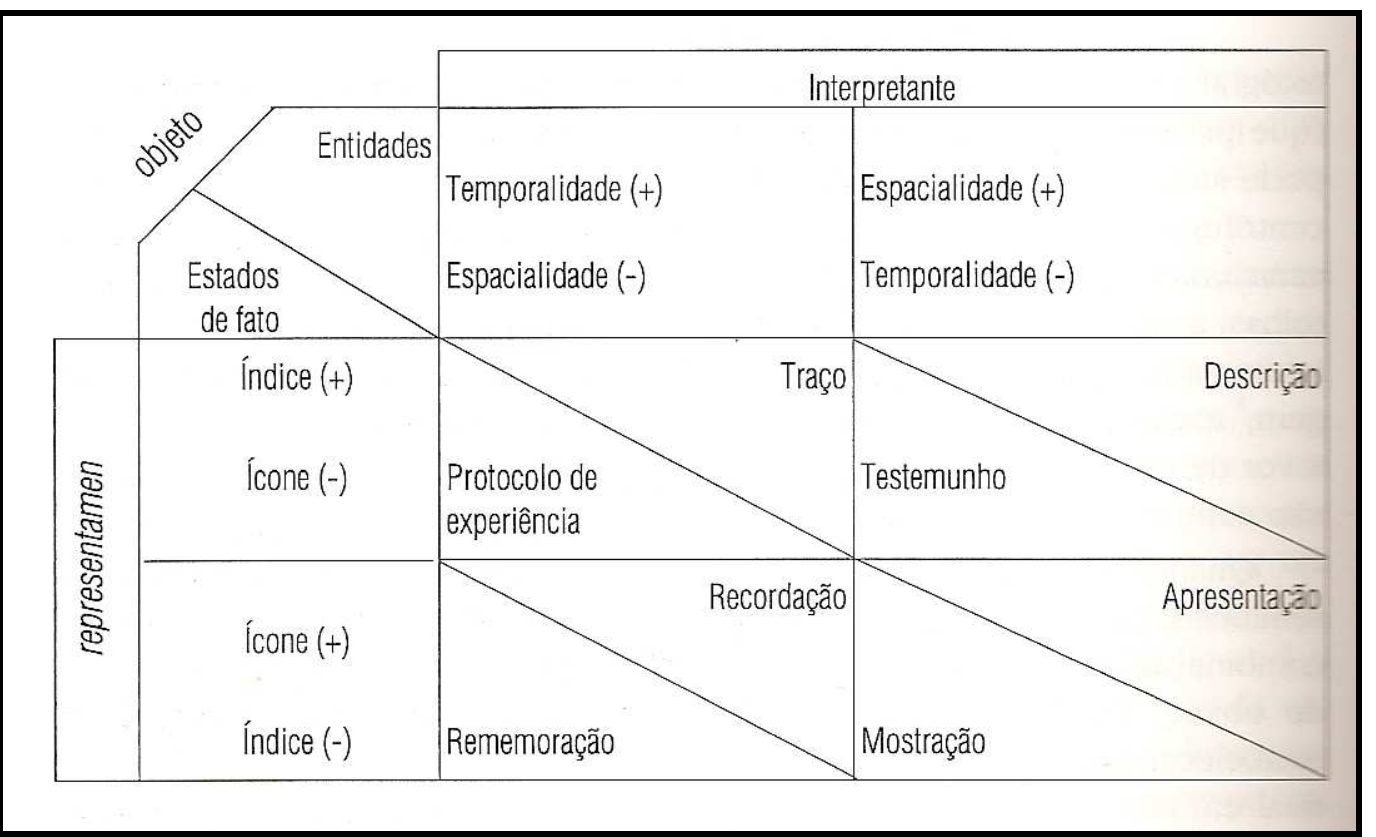

Quadro 1 - O representamen, o interpretante e o objeto (Schaeffer, 1996, p. 66).

Como se pode observar no quadro, o autor define oito funções para a fotografia, que se diferenciam pela predominância ou não do ícone e do índice e 
pela prevalência ou não de temporalidade e espacialidade. A fotografia de recordação é caracterizada por ter predominância de temporalidade em detrimento da espacialidade; predominância do ícone sobre o índice. E por que isso se dá?

Antes de passar para uma explicação pormenorizada da fotografia de recordação, é interessante conhecer as divisões de uso da fotografia, que Manini (2007) enumera:

- Uso comercial: a imagem fotográfica para o marketing. Com esse fim, a imagem fotográfica não precisa ser verdadeira em seu sentido denotativo, mas deve passar tal imagem na idéia que vende. Priorizam-se critérios estéticos, artísticos e ilustrativos;

- Uso para exposição/publicação: uma imagem com essa finalidade pode ter diversos fins específicos, como ser publicada num livro ou exibida numa exposição. Assemelha-se à imagem fotográfica de cunho comercial por ser priorizado o critério estético em detrimento da verossimilhança;

- Uso probatório: a imagem fotográfica como prova, testemunho. Prioriza a verossimilhança e a representatividade;

- Uso didático/científico: utilização da imagem fotográfica em eventos de cunho educacional, como aulas e palestras. São fundamentais a verossimilhança, a representatividade e a ilustração, embora alguns campos do conhecimento, como as artes, considerem importantes critérios artísticos e estéticos;

- Uso pessoal/familiar: imagens fotográficas de família e amigos. Nessa categoria predomina a verossimilhança e a representatividade. Critérios artísticos e estéticos, quando aparecem, estão em segundo plano.

\subsubsection{A fotografia de acervo pessoal}

A expressão arquivo pessoal é corrente na literatura e, portanto, seria a mais adequada a ser utilizada neste trabalho. No entanto, optou-se por utilizar a 
expressão acervo pessoal, que pode ser melhor associada com a coleção de imagens fotográficas de cunho pessoal e, geralmente, de valor sentimental, ao passo que arquivo traz uma idéia mais técnica e objetiva, desprovida de emoção.

Sobre a fotografia, Kossoy (2001, p. 131), afirma que "é ao mesmo tempo, uma forma de expressão e um meio de informação e a comunicação a partir do real e, portanto, um documento da vida histórica". O autor também diz que:

A experiência visual do homem quando diante da imagem de si mesmo, retratado por ocasião das mais corriqueiras e importantes situações de seu passado, leva à reflexão do significado que tem a fotografia na vida das pessoas. (KOSSOY, 2001, p. 99)

Partindo-se destas afirmações, pode-se fazer um paralelo com a ideia de Ribeiro (1998), sobre o que ele chama de "coleção de si" em seu artigo. O autor coloca que: "o desejo de perpetuar-se, mas, mais que isso, o de construir a própria identidade pelos tempos adiante, responde ao anseio de forjar uma glória". Como elemento iconográfico dos arquivos pessoais, a fotografia tem a essência de registro para a posteridade. Traz a idéia de que o dono do arquivo queira recordar e transmitir os momentos que registrou. Garat (apud Artière, 1998) afirma que:

Em toda família, existe, com efeito, o hábito de dedicar regularmente longas
tardes a reunir e a organizar as fotos relacionadas com a vida de cada um
dos seus membros. Um casamento, um nascimento, uma viagem são objeto
de uma ou de várias páginas. Não colamos qualquer foto nos nossos
álbuns. Escolhemos as mais bonitas ou aquelas que julgamos mais
significativas; jogamos fora aquelas em que alguém está fazendo careta, ou
em que aparece uma figura anônima. E depois as ordenamos esforçando-
nos para reconstituir uma narrativa. Quando a foto é muito enigmática,
acrescentamos um comentário.

Identifica-se até aqui todo o ritual que envolve o ato de recordar o passado, onde a família se reúne para reviver momentos muitas vezes importantes e marcantes, que fizeram parte de sua trajetória. Geralmente essas imagens evocam lembranças agradáveis, mas: 


\begin{abstract}
Acontece também, com o tempo, de algumas fotos serem retiradas, porque são comprometedoras, porque não são condizentes com a imagem que queremos dar de nós mesmos e da nossa família. Pois o álbum de retratos constitui a memória oficial da família; (...) No álbum, fazemos figurarem (sic) também os nossos antepassados; aí também trata-se (sic) de comprovar que pertencemos a uma linhagem, que temos raízes. (...) Se as ausências nos álbuns são toleradas, não manter arquivos fotográficos da família, em compensação, constitui uma falta. É um dever produzir lembranças; não fazê-lo é reconhecer um fracasso, é confessar a existência de segredos. O álbum é uma garantia de transparência, um passaporte de sinceridade e uma prova de ajustamento (GARAT apud ARTIËRE, 1998).
\end{abstract}

Fica clara a grande importância que a fotografia tem na vida das pessoas. A fotografia, principalmente como forma de recordação, tem grande valor - talvez não tão latente - no que diz respeito à memória de uma pessoa. Como já foi dito, não é muito comum ver alguém que não esteja relativamente "bem" na foto. Há a necessidade de deixar registrada uma imagem positiva, ainda que manipulada, para a posteridade, o que Ribeiro (1998) chama de "reconhecimento por uma identidade digna de glória”.

Kossoy (2001, p. 100) diz, sobre a fotografia, que "estamos envolvidos afetivamente com os conteúdos dessas imagens; elas nos dizem respeito e nos mostram como éramos, como eram nossos familiares e amigos.".

Dado o status importante das imagens fotográficas, faz-se necessário que estas sejam devidamente organizadas da melhor maneira possível, de forma a facilitar o acesso do dono do arquivo às suas próprias memórias, ou permitir o acesso de outros que estejam autorizados e/ou que possam vir a se interessar.

A necessidade de organização se torna ainda mais latente com as imagens fotográficas, pois o usuário, que geralmente transfere um grande número de imagens da máquina fotográfica digital para o computador, pode encontrar dificuldades no momento em que quiser organizar seus arquivos. Isso ocorre porque, ao serem transferidas, as imagens não trazem outra informação adicional que não seja um código de números e/ou letras como título. A resposta para esse problema pode ser encontrada na indexação. 


\subsection{Indexação de imagens}

Cavalcanti e Cunha (2008) definem indexação como "a representação do conteúdo temático de um documento por meio dos elementos de uma linguagem documentária ou de termos extraídos do próprio documento". Para Duque (2006, p. 799), a indexação "é um processo que consiste em nomear palavras-chave de um documento (as palavras-chave são a representação do documento)". Oliveira (2009, p. 15), por sua vez, oferece-nos uma definição mais clara e simples. Ela define indexação "como a atividade de elaborar índices de assuntos, nomes e lugares".

De acordo com Lancaster (2004), o propósito da indexação é criar representações dos documentos para que eles sejam incluídos em bases de dados. Como o foco deste trabalho é a indexação de imagens, faz-se necessário uma abordagem mais específica da indexação.

Lancaster afirma que a indexação de imagens se diferencia da indexação de textos porque o usuário, ao buscar as primeiras, tem uma gama de variedades na busca, podendo realizá-la tanto por nome de artista, título da obra até cor, textura e dimensões. Tanta variedade acaba gerando problemas. Afinal, qual é a melhor forma de indexar as imagens? Que atributos levar em consideração?

Cleveland e Cleveland (2001) afirmam que, desde a década de 1960, profissionais da informação discutem e pesquisam sobre o problema da indexação de imagens, e que no decorrer dos anos, a discussão continua. Ainda não se chegou a um modelo preciso de indexação de imagens.

Miranda (2007), na introdução de sua dissertação de mestrado, destaca dois grandes grupos de indexação de imagens: indexação com base no conteúdo e indexação com base em conceitos, sendo o primeiro baseado em análises computacionais, que levam em consideração aspectos como cor e textura da imagem, e o segundo atribuindo palavras-chave "que se referem às informações presentes na imagem". Como esse trabalho tem como foco a indexação de acervos pessoais, vamos nos ater ao segundo grupo, indexação com base em conceitos. 


\title{
5.2.1 Indexação com base em conceitos
}

Lancaster (2004) define indexação com base em conceitos como a descrição de imagens feita por humanos utilizando a linguagem textual. Atribuir conceitos às imagens, num processo de tradução de linguagem iconológica para linguagem verbal.

A indexação com base em conceitos é uma técnica bastante pesquisada. Isso se deve ao fato de ter maior aplicabilidade que a indexação com base no conteúdo, uma vez que a maioria dos usuários de bases de dados de imagens provavelmente não fará buscas sobre aspectos mais abstratos como cor, forma e textura, o foco da indexação com base no conteúdo (Lancaster, 2004).

Miranda (2007) divide a indexação com base em conceitos em dois grupos: representação do conteúdo visual da imagem e representação do conteúdo não visual.

A representação do conteúdo visual consiste em representar elementos da imagem utilizando descritores, palavras-chave. É a tradução da informação iconográfica para a informação escrita.

A respeito da representação do conteúdo não visual, o autor afirma:

\begin{abstract}
A representação do conteúdo não visual está relacionada com a descrição da informação extrínseca à imagem, ou seja, a informação que não está presente na imagem, mas que de alguma forma está relacionada a ela e que pode ser útil para melhorar a recuperação de imagens (MIRANDA, 2007, p. 28)
\end{abstract}

A representação do conteúdo não visual abarca a interpretação da imagem. É a análise da imagem como símbolo e índice.

Miranda alerta para o fato de que, como em toda tradução, na indexação com base no conteúdo há perda de informação, uma vez que o indexador nunca conseguirá representar verbalmente com precisão plena a informação imagética. $\mathrm{E}$ tamanha é a dificuldade de realizar essa representação de forma satisfatória, que 
Jörgensen (1996) lembra que diversos estudos têm sido realizados buscando desenvolver um bom sistema de recuperação de imagens, mas, até agora, os sistemas desenvolvidos sempre são voltados para grupos específicos de usuários ou imagens, o que diminui a abrangência do sistema, o qual, para atender bem a um grupo de usuários, precisa abrir mão de muitos grupos de usuários.

A seguir, uma breve abordagem da obra de três autores que criaram modelos de indexação de imagens com base em conceitos e que são muito citados na literatura sobre o assunto: Erwin Panofsky, Sara Shatford e Corinne Jörgensen. Objetiva-se conhecer os modelos propostos a fim de verificar se podem ser úteis para o problema citado nesse tópico.

\subsubsection{Níveis de análise da imagem de Panofsky}

Dentro da indexação de imagens baseada em conceitos, provavelmente um dos modelos mais conhecidos é o proposto por Erwin Panofsky, historiador de arte. $\mathrm{O}$ autor propôs que a análise da imagem fosse dividida em três níveis: préiconográfico, iconográfico e iconológico. Baseando-se em Smit (1996), os três níveis podem ser assim definidos:

- Nível pré-iconográfico: descrição genérica dos objetos e ações representados na imagem, de seu referente;

- Nível iconográfico: descreve o assunto secundário ou convencional ilustrado pela imagem. Trata-se da determinação do significado mítico, abstrato ou simbólico da imagem, sintetizado a partir de seus elementos componentes, detectados pela análise pré-iconográfica. Panofsky (1991, apud Manini, 2002, p. 54) lembra que "esse nível depende do anterior, já que o reconhecimento de assuntos e conceitos pressupõe que se tenha identificado corretamente os motivos primários"; 
- Nível iconológico: nesse terceiro nível, Panofsky propõe a interpretação do significado extrínseco do conteúdo da imagem. A análise iconológica constróise a partir das anteriores, mas, conforme Manini (2002) depende de significados/conteúdos somente detectáveis levando-se em conta o contexto da imagem fotográfica (ou do indexador), seja ele cultural, social, filosófico ou ideológico. Nesse nível não é possível haver perfeita sintonia entre a intenção do emissor e a imaginação do receptor.

Shatford (1986, p. 45) resume da seguinte forma os três níveis de Panofsky: "[O nível] pré-iconográfico é uma descrição, [o nível] iconográfico é uma análise e o iconológico é interpretação".

Baseando-se nos níveis de Panofsky, é possível indexar a imagem abaixo da seguinte forma:

Pré-iconográfico: Cachorro, Cão;

Iconográfico: Vira-Lata, Animal de estimação, Mila;

Iconológico: Euforia, Alegria. 


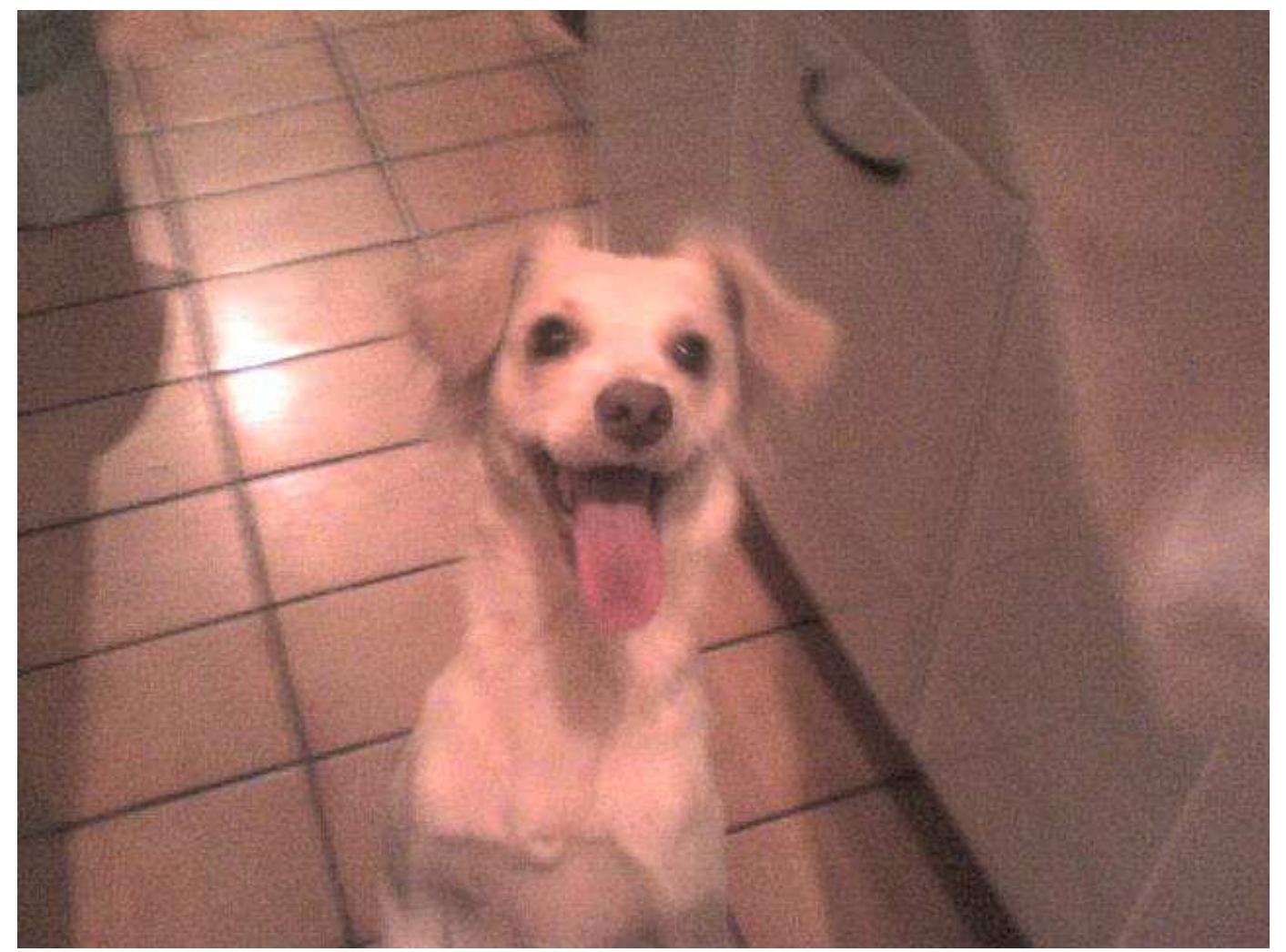

Figura 13 - Mila / Ruthléa Nascimento - Acervo pessoal.

\subsubsection{Modelo de Jörgensen}

Corinne Jörgensen (1996) afirma que o maior problema intelectual envolvendo a indexação de imagens é como indexá-las. Isso ocorre, segundo ela, por falta de estudos sobre a percepção humana de imagens pictóricas. Não é possível realizar uma boa indexação de imagens sem compreender como o ser humano "lê", compreende a imagem. Fazê-lo seria semelhante a traduzir um texto da língua espanhola para a língua portuguesa sem compreender bem os idiomas.

Porém, a falta de compreensão sobre a percepção humana de imagens não impediu que fossem desenvolvidos inúmeros sistemas de indexação de imagens, só que esses sistemas tendem a ser desenvolvidos visando a alvos específicos, limitando o acesso às imagens, o que pode piorar ainda mais com o rápido aumento 
das imagens digitais e coleções de imagens. Jaim (1993 apud Jörgensen 1996) afirma que o número de imagens digitais aumenta na casa dos milhões diariamente.

Buscando resolver o problema, Jörgensen realizou estudos com a comunidade acadêmica para compreender como o ser humano percebe as imagens pictóricas e assim chegou a três classes de atributos de imagens:

- Atributos descritivos: são assim denominados por serem resposta direta a estímulos visuais como cor ou objetos;

- Atributos interpretativos: são aqueles que requerem interpretação dos atributos descritivos, o que se faz com algum conhecimento e geralmente leva a idéias abstratas;

- Atributos reativos: descrevem reações pessoais às imagens, sensações que as imagens despertam nas pessoas, como confusão, incerteza.

Para uma melhor compreensão do modelo de Jörgensen, a Figura 14 foi indexada utilizando as três classes de atributos criadas pela autora. Dentre os atributos descritivos, obtiveram-se termos como: pessoas, gramado e refeição. Como atributos interpretativos, os termos: reunião, confraternização e Universidade de Brasília (UnB). Já como atributos reativos, obtiveram-se os termos: amizade, alegria, união e até mesmo nostalgia. 


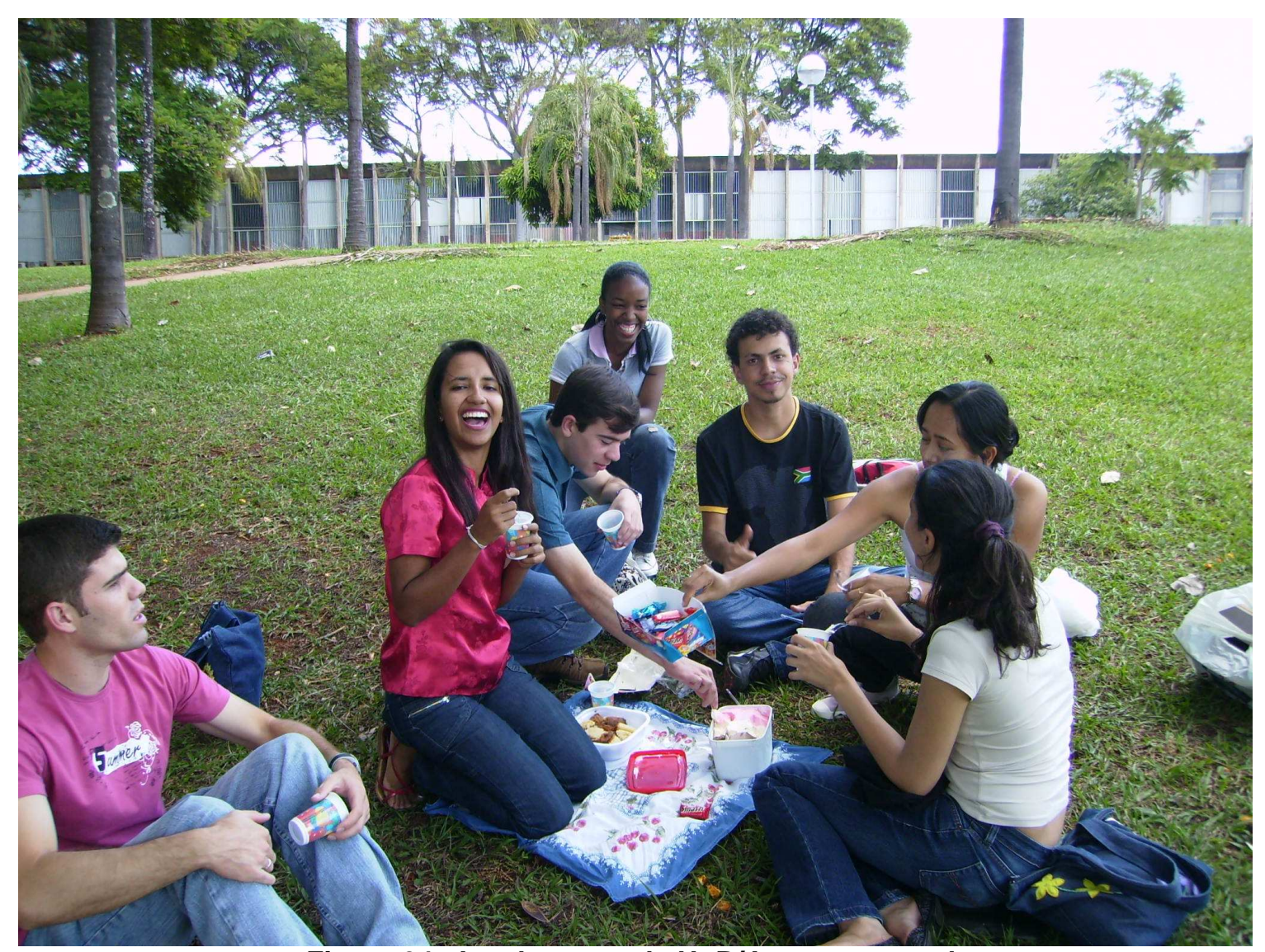

Figura 24 - Lembranças da UnB/Acervo pessoal.

\subsubsection{Modelo de Shatford}

Em artigo publicado em 1986, Sara Shatford busca analisar o objeto da imagem e seu significado, e fazer uma proposição teórica. Para a autora, é muito difícil indexar uma imagem baseando-se em seu significado porque essa pode ter diversos significados para diversas pessoas. Porém, indexá-la baseando-se no que ela mostra pode significar menor recuperação na hora da busca. Um usuário que busca imagens que representam a vaidade, dificilmente a encontraria se a imagem de um pavão fosse indexada apenas como pavão, como a própria autora exemplifica.

A autora baseia-se nos três níveis de Panofsky para afirmar que uma imagem representativa é de e sobre alguma coisa, sendo que o de se divide em de 
genérico e de específico. A autora comenta que, assim como o de, o sobre também pode se subdividir em genérico e específico em alguns casos. Isso se deve ao fato de estar relacionado a palavras que descrevem emoções e conceitos abstratos, naturalmente imagináveis como genéricos.

Como exemplo do que foi dito acima, Shatford cita o retrato "Mrs. Siddons as the Tragic Muse", de Joshua Reynolds e ressalta que a imagem da Sr. Siddons pode ser sobre Melpomene ${ }^{10}$, que é um exemplo específico da Musa genérica.

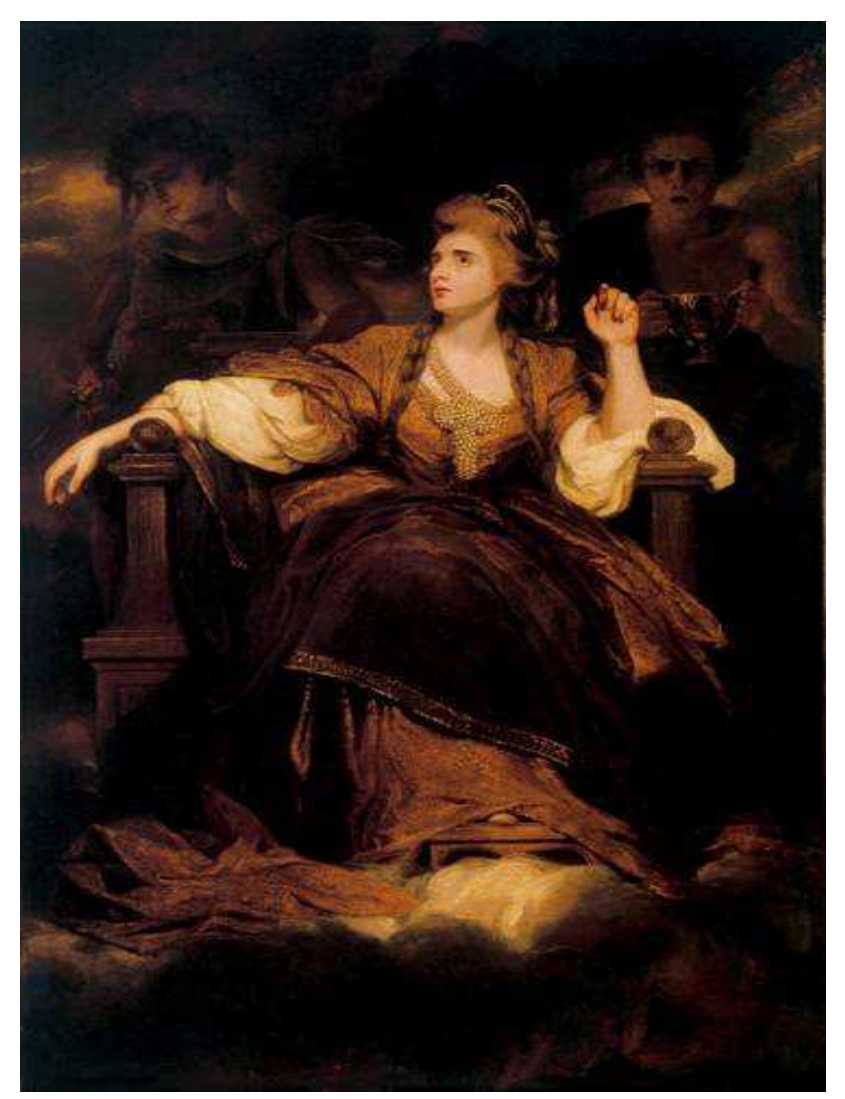

Figura 15 - "Mrs. Siddons as the Tragic Muse", de Joshua Reynolds/Fonte: Royal Academy of Arts $<$ http://www.royalacademy.org.uk/exhibitions/citizensandkings/the-allegoricalportrait,321,AR.html>. Acesso em: 16/11/2009.

Para se fazer uma melhor análise, a autora propõe que sejam respondidas as seguintes perguntas associadas ao de e ao sobre:

\footnotetext{
${ }^{10}$ Uma das nove musas da Mitologia Grega. Considerada a musa da tragédia, embora seu canto fosse alegre.
} 


\section{Quem?}

- De quem é esta foto, especificamente?

- De quem é esta foto, genericamente?

2. O quê?

Descreve eventos, ações, condições e emoções.

- O que os envolvidos nesta imagem estão fazendo?

- Quais são suas condições ou estado de existência?

- Que emoções são transmitidas por essas ações ou condições?

- Que ideias abstratas essas ações ou condições simbolizam?

\section{Onde?}

Refere-se a espaços geográficos, cosmográficos e arquitetônicos, ou seja, ao local retratado na imagem.

- Em que espaço está localizada a imagem?

No de genérico, o onde se refere a tipos de lugar e, no sobre, subdivide-se em duas perguntas:

a. O local representa um lugar diferente ou mítico? Exemplo: Monte Olimpo;

b. O local representa a manifestação de um pensamento abstrato? Exemplo: Paraíso.

\section{Quando?}

Envolve datas específicas, períodos e tempos recorrentes (dia, noite, estações do ano). O tempo linear pode ser descrito por termos no de específico e o tempo cíclico no de genérico. O sobre é raramente usado nesta faceta, mas possui termos que respondem à seguinte questão: o elemento de tempo representado na imagem é uma manifestação de uma ideia abstrata? A autora cita como exemplo "A primavera", de Botticelli, onde se nota uma alegoria. E completa, afirmando que 
"uma imagem de primavera pode ser sobre esperança ou fertilidade ou juventude" (SHATFORD, 1986, p. 54, tradução nossa).

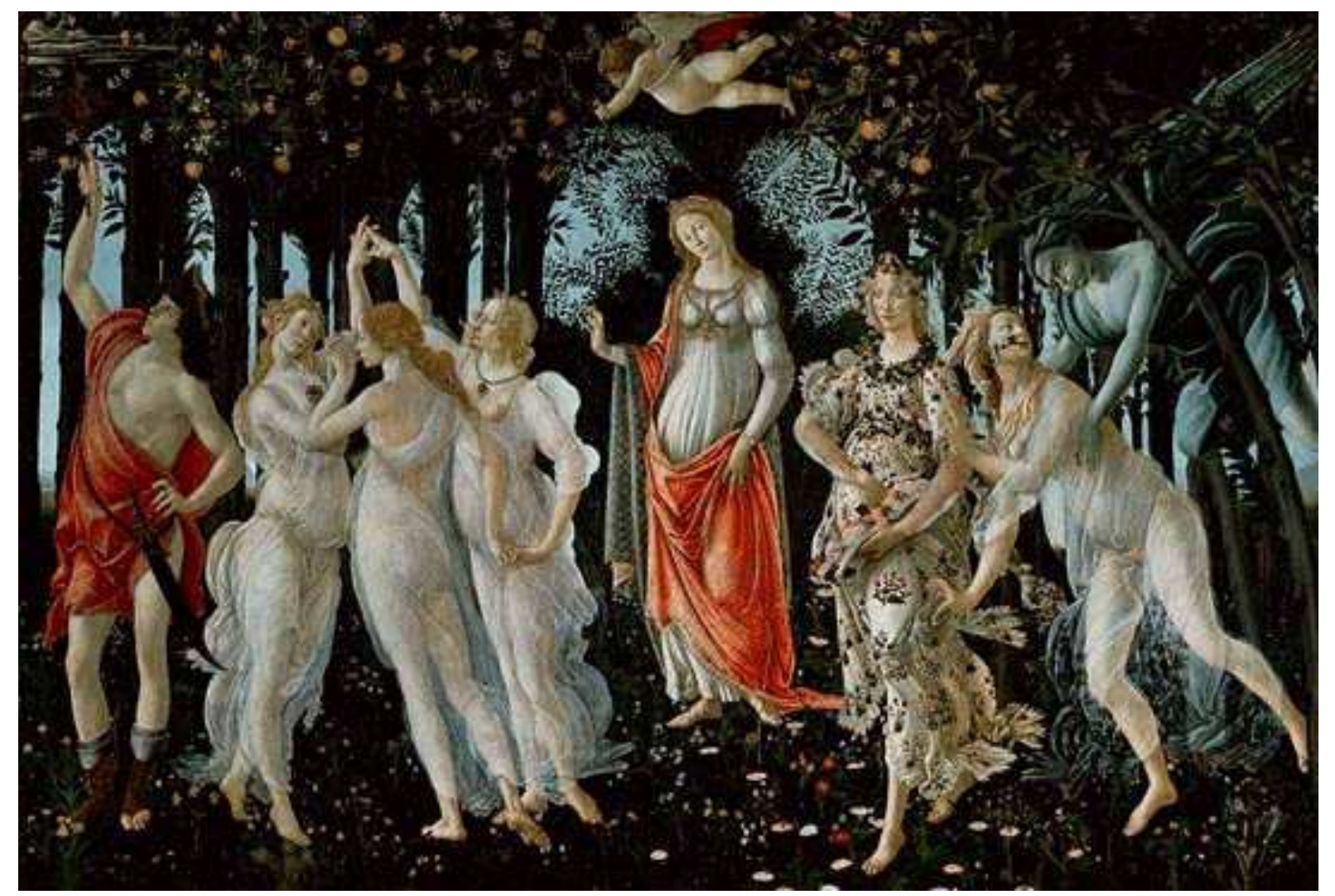

Figura 25 - "A primavera", de Botticelli/Fonte:

$<$ http://www.storiadellarte.com/biografie/botticelli/immbott/la\%20primavera.htm>. Acesso em: 16/11/2009.

Dependendo da necessidade do usuário leigo, ele pode definir um ou mais termos para o de e o sobre. Não existe a obrigatoriedade de responder todas as perguntas propostas acima, pois há casos em que simplesmente não há o que se colocar.

Shatford alerta que a reprodução de uma pintura, por si só, é um tipo de assunto, que pode ser descrito de acordo com as normas criadas para o catálogo descritivo. Ou seja, no caso do usuário leigo, ele pode decidir qual a maneira mais eficaz de utilizar a descrição a seu favor. 


\subsection{Folksonomia}

Folksonomia é um neologismo criado pelo arquiteto da informação Thomas Vander Wal a partir das palavras folk (povo) e taxonomy (taxonomia), ou seja, uma taxonomia criada pelas pessoas. Wal (2006, apud Catarino e Baptista 2007), afirma que folksonomias são criadas quando pessoas atribuem etiquetas a informações ou objetos visando à sua recuperação, atribuição essa que ocorre livremente e é feita com critérios pessoais. Porém, definir o conceito de folksonomia não é tarefa fácil. As definições para o termo na literatura variam bastante. Há quem defina como sendo um processo e até quem defina folksonomia como um vocabulário ou uma indexação livre em linguagem natural. $O$ único consenso entre os autores é que se trata de algo feito pelo usuário para o usuário (CATARINO E BAPTISTA, 2007). Para esse trabalho, é interessante defini-la levando em consideração as definições apontadas pela literatura científica, como: a atribuição de palavras-chave em linguagem natural sem um controle ou vocabulário controlado.

Tal como a Web $2.0^{11}$, a folksonomia vem se popularizando cada vez mais, sendo utilizada inicialmente em redes sociais, mas, ultimamente, em sites comerciais como o da Amazon® (Neal, 2007). Para as empresas, a folksonomia representa um elo a mais entre elas e seus clientes.

A grande vantagem da folksonomia na Web é a liberdade que proporciona ao usuário que pode atribuir termos e recuperá-los posteriormente, além da interação com os sites (interação essa que é a marca da Web 2.0). Outra vantagem da folksonomia, especialmente em se tratando das imagens, é que o usuário, ao atribuir os termos, geralmente já possui conhecimento prévio sobre o assunto, o que Schaeffer (1996) chama de conhecimento lateral, a interpretação identificante.

Ora, quem pode melhor conhecer a imagem do que seu autor? Evita-se erros; afinal, como diz Schaeffer:

\footnotetext{
${ }^{11}$ Web 2.0: termo criado por Tim O'Reilly em 2005, assim definido por ele: plataforma onde são compartilhados todos os dispositivos conectados (Catarino e Baptista, 2007). A web 2.0 diferencia-se de sua antecessora por ter como carro-chefe o compartilhamento, a troca de informações.
} 
O interpretante, mesmo se quisesse, não conseguiria reencontrar 0 conhecimento lateral e a intencionalidade do fotógrafo, não importa quanto se esforçasse para perscrutar a imagem. (SCHAEFFER, 1996, p. 76)

Com a imagem fotográfica a seguir (Figura 17), é possível perceber claramente o que Schaeffer quis dizer sobre interpretante e conhecimento lateral. Tem-se a imagem de um pinscher que aparenta estar nervoso, rosnando para alguém. No entanto, a imagem foi capturada enquanto a pintcher brincava com outra cadelinha e, na verdade, não estava nervosa e tampouco rosnando. Tal informação, porém, só se faz conhecida pela fotógrafa ou com a ajuda de uma legenda, caso a fotógrafa a insira junto com a imagem.

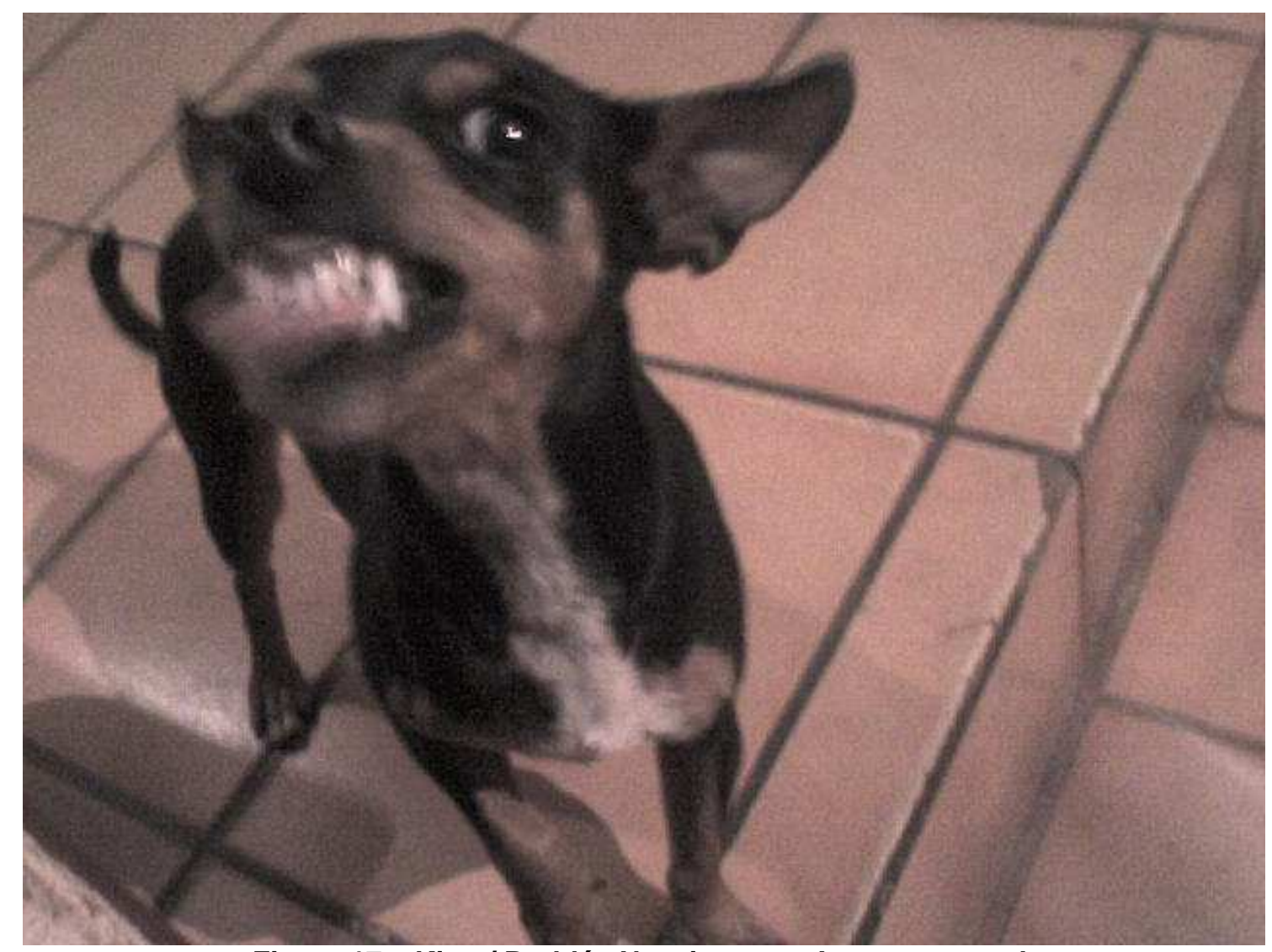

Figura 17 - Kitty / Ruthléa Nascimento - Acervo pessoal.

Mas, assim como apresenta boas vantagens, a folksonomia também apresenta problemas, semelhantes aos da indexação, como os profissionais da informação a conhecem. 
Um dos problemas da folksonomia e da indexação de imagens é a relevância. Cleveland e Cleveland (2001) afirmam que o problema da relevância é que ela muda conforme a necessidade do usuário e seu contexto, ou seja, o significado de uma imagem muda conforme a perspectiva do individuo, o que é confirmado por Lopes ao afirmar que a análise da imagem é denotativa (o que mostra) e conotativa (o que se entende). Nem sempre o que uma pessoa considera um bom critério de busca 0 será para outra pessoa ou mesmo para ela mesma depois de algum tempo.

Ainda tratando dos problemas causados pela folksonomia, Catarino e Baptista (2007) e Gouvea e Loh (2007) citam a polissemia, a sinonímia e a ambiguidade, que acontecem exatamente porque a folksonomia é realizada sem padrões, critérios prédefinidos e objetivos. Cada um atribui as etiquetas que the parecem mais convenientes, sem analisar se outros usuários julgarão o mesmo, problema esse que se torna ainda maior quando se trata de atribuir etiquetas a imagens, elas próprias subjetivas. Como exemplo disso, vejamos as Figuras 18, 19 e 20.

Nesse exemplo, realizou-se uma busca na rede social Flickr® onde usuários podem publicar suas imagens fotográficas e atribuir etiquetas a elas. A etiqueta selecionada foi dia nublado. A escolha se deu por já se ter conhecimento prévio da existência da imagem fotográfica na Figura 18 com a etiqueta: 


\section{Rodoviária e torre de TV}

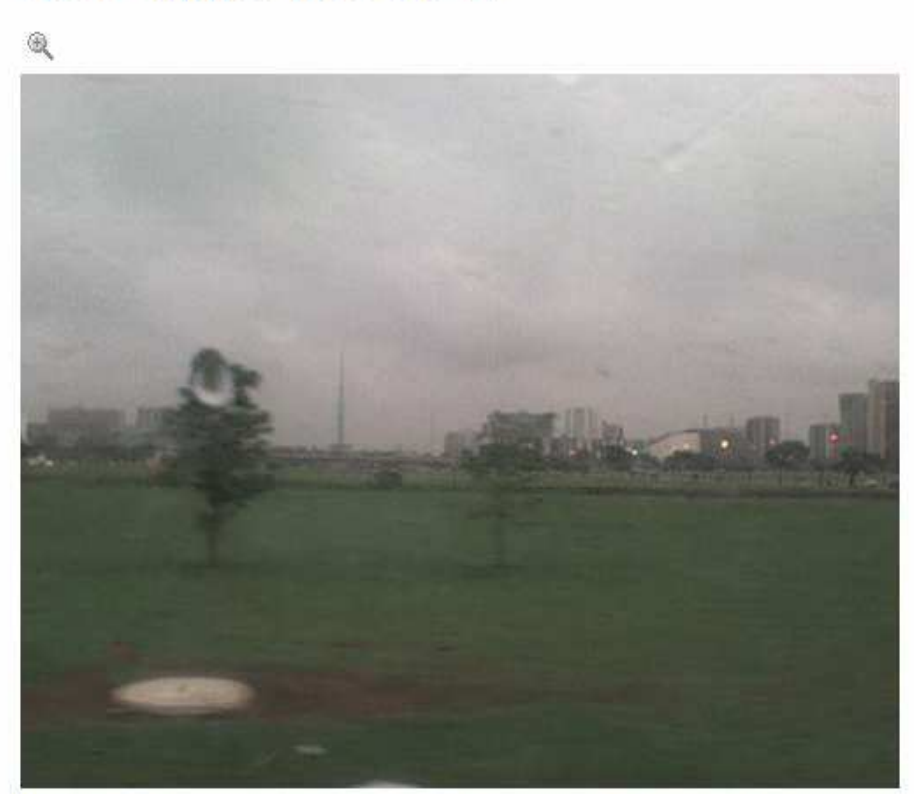

Um dia bem frio e chuvoso (como eu amo!) no Plano Piloto, em Brasilia, às 9 da manhã. Vista do 110 indo pra UnB.
6. Upload feito em 22 de julho de 2009 por Ruth nascimento
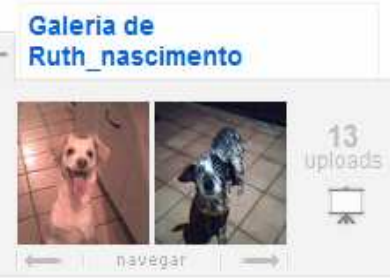

Tags

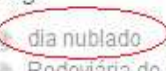

Rodoviaria do Plano Piloto

Torre de TV

Plano Piloto

Brasilia

Informações adicionais

(C) Todos os direitos reservados

Qualquer pessoa pode ver esta foto

Tirada com um(a) Sony Ericsson W300i Mais propriedades

- Tirada em 6 de novembro de 2007

Figura 18 - Página do Flickr. Disponível em: <www.flickr.com/ruth_nascimento>. Acesso em $16 / 11 / 2009$

Na Figura 19 temos a página de busca com os resultados obtidos. Observase que uma das imagens é uma flor, mas, pesquisando melhor, encontra-se outro resultado que, aparentemente, também difere da etiqueta procurada. 


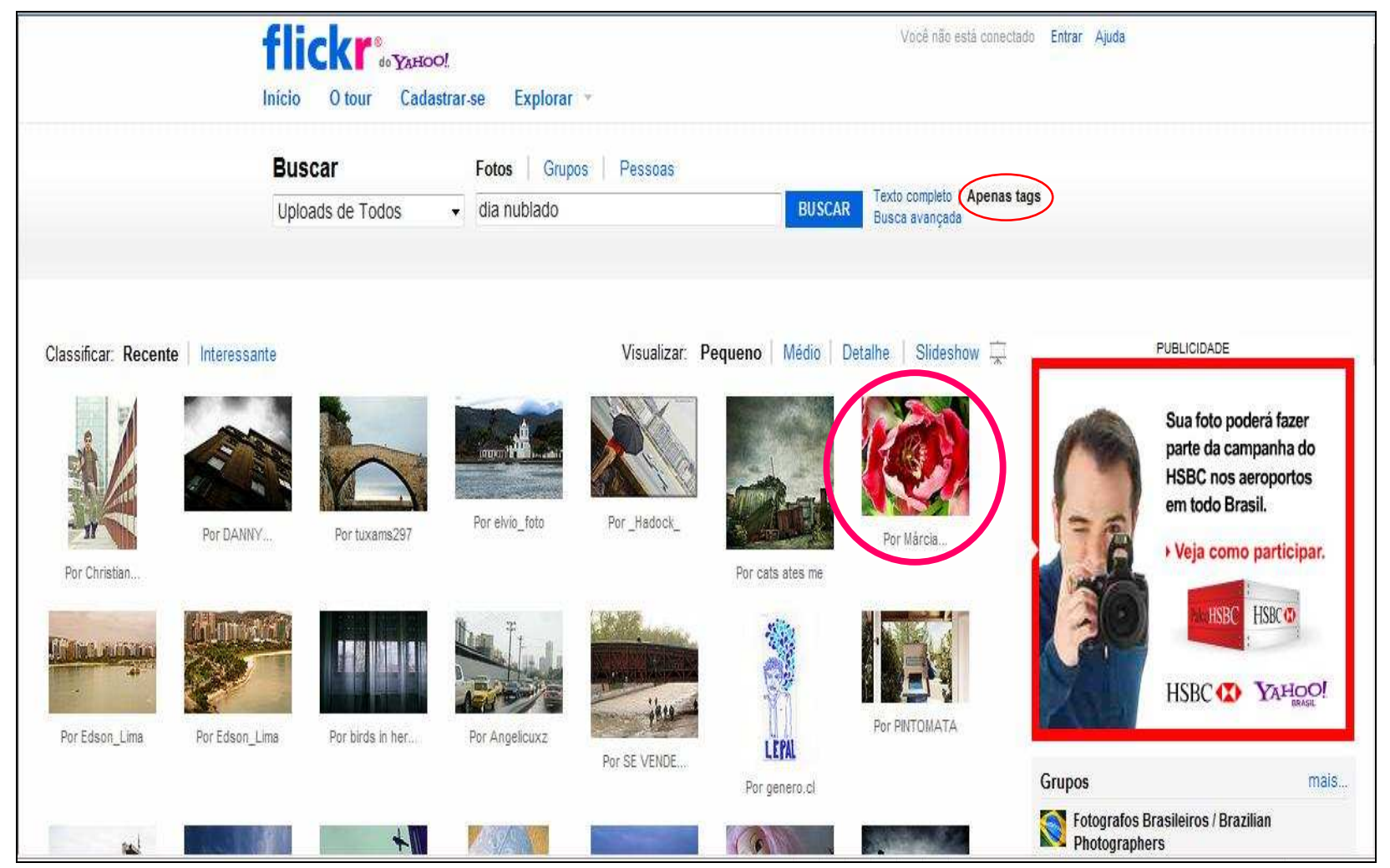

Figura 19 - Página de busca do Flickr. Disponível em: <www.flickr.com>.

A usuária da rede social Paula Ferrari atribuiu, para a imagem fotográfica na Figura 20, intitulada "27ํㅡㄹ andar" várias etiquetas sendo que duas delas foram "dia" e "nublado", recuperadas quando foi buscada a expressão "dia nublado". A legenda informa que a fotografia foi retirada num dia nublado, mas a foto em si não dá qualquer indicação desse fato e, a menos que esse dia tenha sido marcante para a fotógrafa, se perder a legenda por alguma razão, "dia" e "nublado" podem deixar de fazer sentido até para ela. E para alguém que não conhece a fotógrafa e o contexto da foto, recuperar essa fotografia para a busca de "dia nublado" seria perda de tempo. 


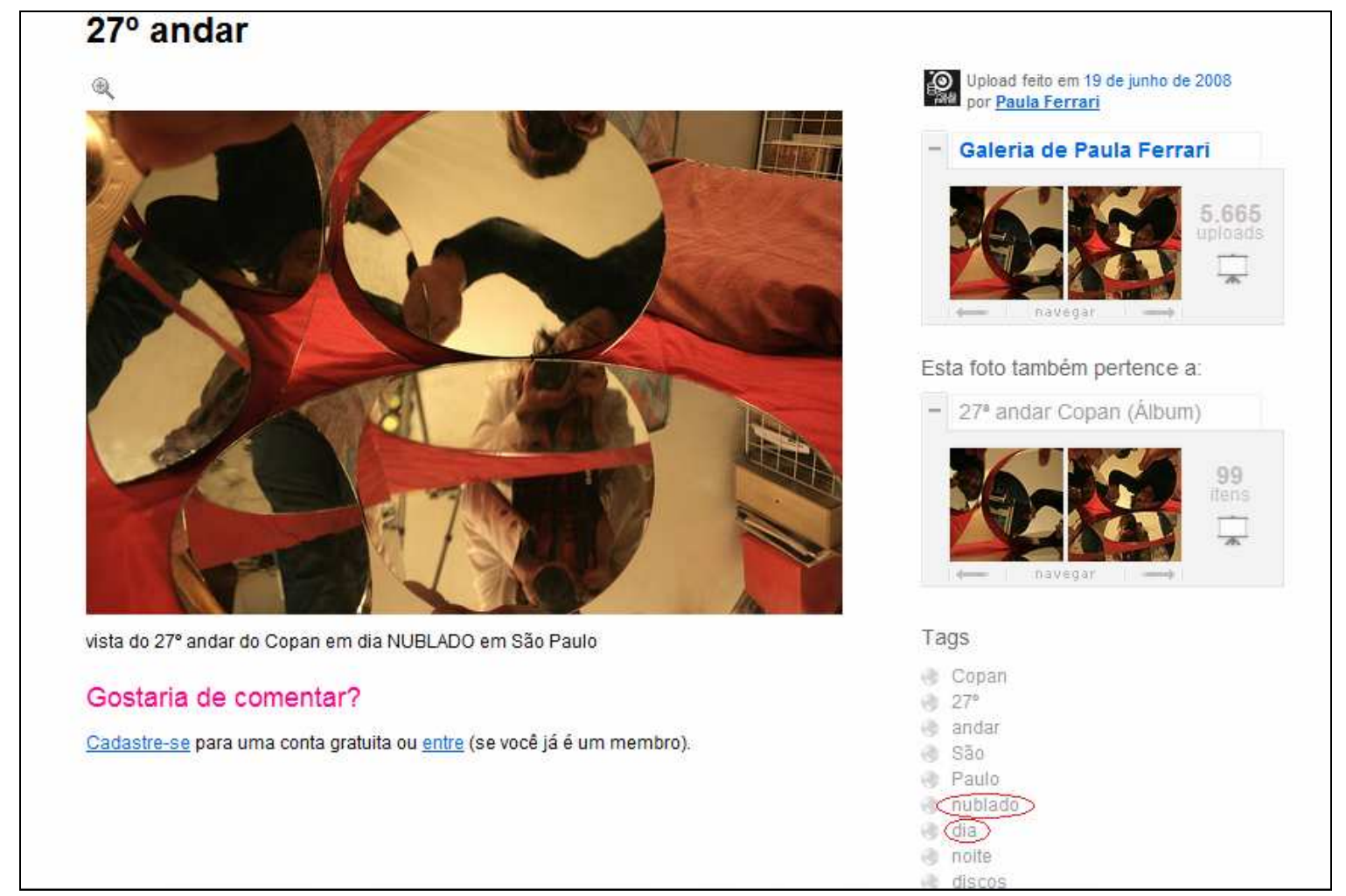

Figura 20 - Página do Flickr. Disponível em: <www.flickr.com/photos/paulaferrari/2593575020> Acesso em 16/11/2009.

Pettersson (1988, apud Shatford Layne, 1994) desenvolveu um estudo onde solicitava aos 97 participantes que atribuíssem termos de indexação para cinco imagens. Dos 43 termos diferentes atribuídos, o autor percebeu que os termos mais comuns eram os principais e mais objetivos, em níveis descritivos, e concluiu que haverá menos coerência nos aspectos secundários e subjetivos, o que reafirma o grande problema da folksonomia. 


\section{A FOLKSONOMIA NA INDEXAÇÃO DE IMAGENS FOTOGRÁFICAS DE ARQUIVOS PESSOAIS}

Como já foi dito na introdução, o usuário leigo costuma utilizar a folksonomia na hora de realizar a indexação de suas imagens e acaba tendo problemas na hora da recuperação pelos motivos que já foram citados. Após a leitura dos conceitos, viu-se que, em sua definição mais ampla, a folksonomia é utilizada pelo usuário leigo não apenas na Web, mas também em seu computador e outros suportes tecnológicos sem que haja necessariamente relação com a internet.

Um exemplo de utilização da folksonomia que pode ser encontrado no computador pessoal é a Galeria de Fotos do Windows, aplicativo do Windows Vista ${ }^{\circledR}$ Home Premium. Abaixo uma imagem que foi indexada usando o programa citado:
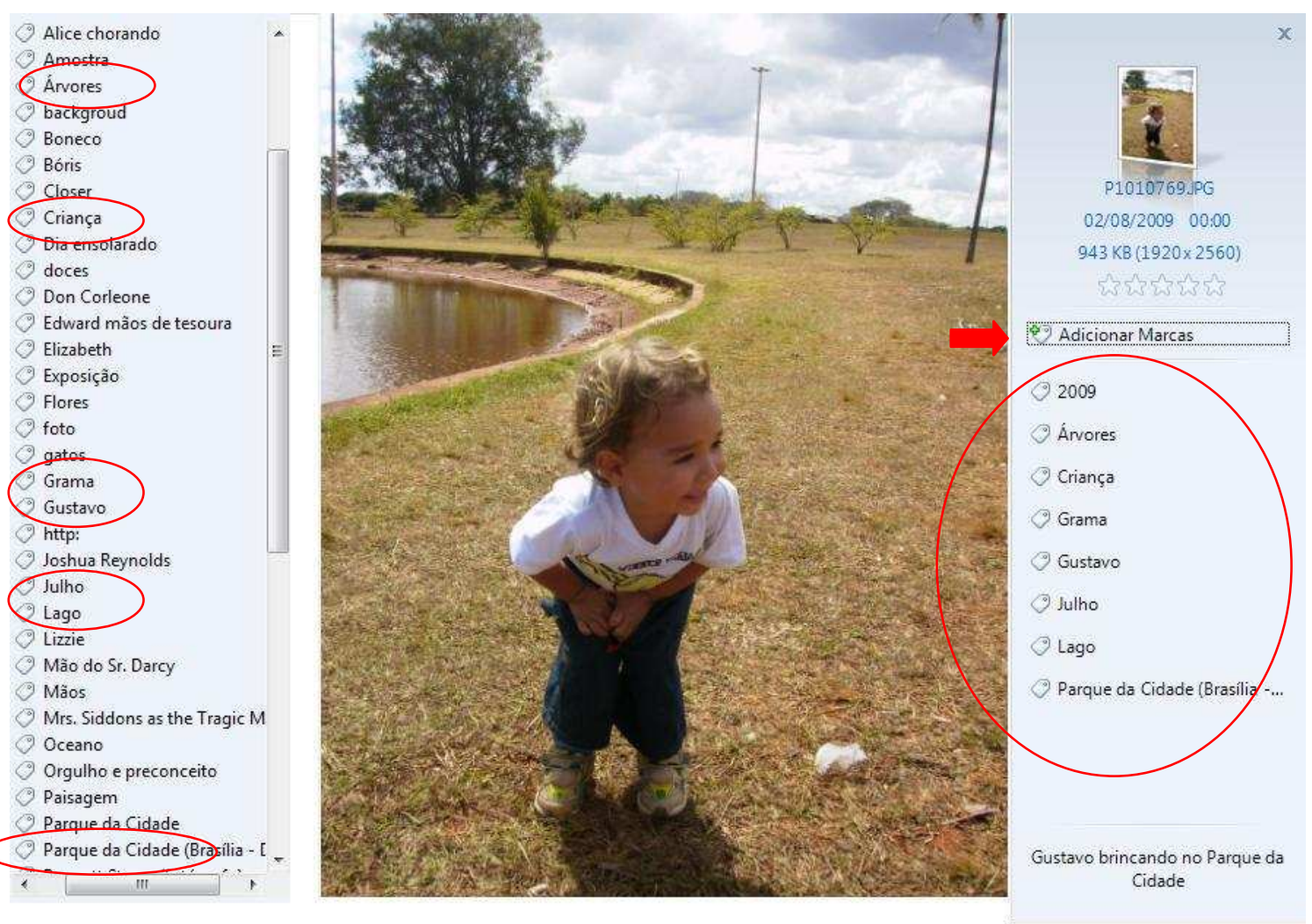

Figura 21 - Gustavo/ Kelly - Acervo pessoal. 
O programa ainda permite que o usuário navegue pelas etiquetas que já foram criadas, por datas (ano, mês e dias), pela classificação (quantidade de estrelas atribuídas às imagens) e pela pasta em que as imagens estão localizadas, como pode ser visto abaixo:

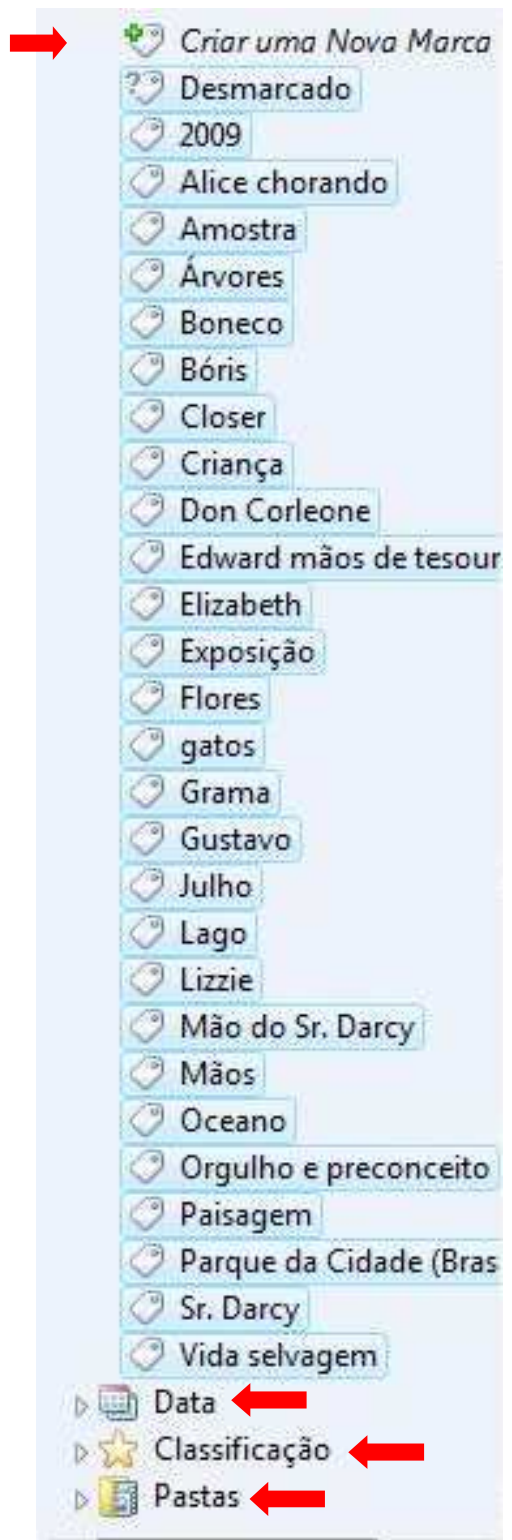

Figura 22 - Janela de navegação da Galeria de imagem do Windows Vista® Home Premium.

Após a análise dos modelos de indexação de imagens de Shatford, Jörgensen e Panofsky, percebe-se que o método mais recomendável para indexação de imagens de acervos pessoais abarca o segundo nível dos três autores, pois, se uma imagem fotográfica for indexada de acordo com os níveis iconográfico, interpretativo e de específico, obter-se-á resultados mais eficientes na 
hora da recuperação, afinal, levando em consideração, por exemplo, a imagem "Mila": não é interessante para os donos da cadelinha realizar uma busca por cachorro ou euforia. Na hora de realizar a busca por essa imagem, provavelmente eles vão querer a imagem fotográfica da Mila (Figura 13, p. 41).

Quanto aos outros níveis, o primeiro (pré-iconográfico, descritivo e de genérico) é muito generalista e o terceiro nível (iconológico, reativo, sobre) foca-se na abstração. Não faz sentido indexar a foto de um casal de namorados com o termo amor. Caso haja um rompimento na relação, "amor" pode fazer com que a imagem não seja mais recuperada.

Indexar imagens fotográficas de arquivos pessoais requer objetividade por parte do indexador, seja ele um profissional ou um usuário leigo. Sabe-se que é quase impossível afastar a parte afetiva quando se fala de imagens de entes queridos (ou nem tanto), mas é preciso, para haver recuperação posterior. Sobretudo, indexar imagens fotográficas de arquivos pessoais requer conhecimento lateral com relação ao seu conteúdo. 


\section{CONCLUSÕES}

Ao término desse trabalho de conclusão de curso, notou-se que as pesquisas na área de indexação de imagens baseada em conceitos ainda tem muito que avançar. Muitos estudos foram e estão sendo desenvolvidos, mas nenhum garante uma recuperação satisfatória quando as imagens são buscadas por um público diversificado.

Os três estudos identificados na revisão de literatura são muito semelhantes entre si. Panofsky, Jörgensen e Shatford utilizam três níveis de análise de imagens, com diferenças muito sutis entre si e objetivos semelhantes. Nas três pesquisas, percebem-se traços da Semiótica, o que se explica por ser ela a ciência que estuda os signos (as representações) e a imagem é definida por vários autores como sendo um signo, uma representação do objeto.

Em relação à folksonomia, o método tanto pode levar a resultados precisos quanto afastar o usuário do documento almejado. Isso pode acontecer na Web, mas pequenos arquivos pessoais não estão livres, uma vez que diversos fatores influenciam a indexação, entre eles o humor do indexador (ou usuário leigo) ou seu contexto, que pode mudar a qualquer momento.

Quanto aos objetivos propostos, não chegou-se a um modelo de indexação de imagens que atendesse ao problema levantado, mas com a combinação dos modelos analisados, obteve-se os resultados desejados.

Embora tenham sido abrodadas as vantagens e desvantagens da folksonomia, o usuário leigo é quem deve escolher o que mais the é mais útil e prático; já que, geralmente, ele é o responsável pela organização dos próprios arquivos.

Encontrar uma maneira de unir folksonomia e técnicas de organização da informação certamente não é fácil, todavia pode ser um grande passo para a Web Semântica, afinal diminuiria a polissemia, a ambiguidade e problemas correlatos, e ainda abarcaria um grande número de pessoas que identificariam com mais facilidade os termos propostos. Com a explosão imagética, isso se torna essencial para que o usuário leigo possa organizar seus arquivos. 
Esse trabalho não teve pretensões de oferecer a solução para o problema da folksonomia. É um tema longo, que exige uma análise mais apurada. Essa pesquisa buscou apenas indicar um caminho a seguir na organização de arquivos pessoais. 


\section{REFERÊNCIAS BIBLIOGRÁFICAS}

ARTIÈRE, Philippe. Arquivar a própria vida, in Revista de Estudos Históricos., n. $21,1998$.

CATARINO, Maria Elisabete; BAPTISTA, Ana A. Folksonomia: um novo conceito para a organização dos recursos digitais na Web, in Revista DataGramaZero, $v$ 8, $n$ 3, jun. 2007. Disponível em: <http://dgz.org.br/jun07/Art_04.htm>. Acesso em: 01/11/2009.

CAVALCANTI, Cordélia R. O.; CUNHA, Murilo B.. Dicionário de Biblioteconomia e Arquivologia. Brasília: Briquet de Lemos, 2008.

CLEVELAND, Donald B.; CLEVELAND, Ana D. Indexing special subjects areas and formats. In: Introduction to indexing and abstracting. $3^{\underline{a}}$ ed. Greenwood Village: Libraries Unlimited, 2001.

DUBOIS, Philippe. $\mathbf{O}$ ato fotográfico e outros ensaios. 11. ed. Campinas: Papirus, 2008. (Série Ofício de Arte e Forma).

DUQUE, Cláudio Gottschalg. Uma abordagem ontológica para a indexação de documentos eletrônicos através da utilização de linguística computacional. In: Simpósio Nacional de Letras e Linguística, XI e Simpósio Internacional de Letras e Linguística, I, 2006, Uberlândia, Minas Gerais. XI Simpósio Nacional de Letras e Lingüística e I Simpósio Internacional de Letras e Lingüística, 2006. Disponível em: <http://www.filologia.org.br/ileel/artigos/artigo_295.pdf>. Acesso em: 01/11/2009.

FABRIS, Annateresa. Discutindo a imagem fotográfica, in: Domínios da Imagem, Londrina, ano I, n. 1, nov. 2007, p. 31-41.FElJÓ, Fernando. Curso básico de fotografia.

Disponível

em:

<http://www.fernandofeijo.com/curso_basico_fotografia.pdf>. Acesso em: 25/11/2009.

GOUVEA, Cleber; LOH, Stanley. Folksonomias: identificação de padrões na seleção de tags para descrever conteúdos, in RESI: Revista Eletrônica de Sistemas de Informação, Florianópolis, v. VI, p. 1, 2007. Disponível em: $<$ http://revistas.facecla.com.br/index.php/reinfo/article/viewFile/214/118>. Acesso em: 10/10/2009.

GREIMAS, Algirdas J.; COURTÉS, J. Dicionário de Semiótica. 9. ed. São Paulo: Cultrix, 1979.

JÖRGENSEN, Corinne. Indexing images: testing an image description template. In: ASIS 1996 (Annual Conference Proceedings). October, p. 19-24 1996.

KOSSOY, Boris. Fotografia e História. 2. ed. São Paulo: Ateliê Editorial, 2001. 
LANCASTER, F. W. Bases de dados de imagens e sons. In: Indexação e resumos: teoria e prática. 2. ed. Brasília: Briquet de Lemos, 2004.

LIMA, Osvaldo S. Câmara Clara, um diálogo com Barthes. In: LUSOCOM (integrado no III CONGRESSO SOPCOM), 6, 2004, Covilhã, Portugal. Anais eletrônicos... Portugal: Universidade da Beira Interior, 2004. Disponível em: < http://www.bocc.ubi.pt/pag/lima-osvaldo-Camera-Clara7.pdf >. Acesso em: 23/11/2009.

LOPES, Ilza Leite. Diretrizes para uma política de indexação de fotografias. In: MIRANDA, Antonio; SIMEÃO, Elmira (org.). Alfabetização digital e acesso ao conhecimento, v. 4. Série Comunicação da Informação Digital. Brasília: Universidade de Brasília, Departamento de Ciência da Informação e Documentação, 2006.

MANINI, Miriam P. Análise documentária de fotografias: um referencial de leitura de imagens fotográficas para fins documentários. 2002. Tese (doutorado) Universidade de São Paulo, 2002.

Conservar o suporte e preservar a informação: como trataremos os documentos fotográficos no futuro? In: Congreso de Archivología del Mercosur, VII, 2007, Viña Del Mar. VII CAM. Viña Del Mar: Asociación Archiveros de Chile, 2007. v. 1. p. 1.

MARCONDES, M. Conservação e preservação de coleções fotográficas. Boletim do Arquivo, São Paulo: Imprensa Oficial, v. 1, p. 1-7, 2005.

MELPÔMENE. In: Wikipédia. Disponível em: <http://pt.wikipedia.org/wiki/Melpômene>. Acesso em: 10 nov. 2009.

MIRANDA, Alex S. S. Ontologias: indexação e recuperação de fotografias baseadas na técnica fotográfica e no conteúdo. 2007. Dissertação (mestrado) - Universidade de Brasília, 2007.

NEAL, Diane. Introduction - Folksonomies and image tagging: seeing the future?, in Bulletin of the American Society for Information Science and Technology October/November 2007.

NICHOLS, Mike. Closer (Closer - Perto demais). Estados Unidos, 2004. (Filme).

OLIVEIRA, Isabel C. B. Arquivos pessoais, arquivos de memória e o processo de indexação. 2009. Dissertação (mestrado profissional) - Fundação Getúlio Vargas, Centro de Pesquisa e Documentação de História Contemporânea do Brasil (CPDOC), 2009.

PEIRCE, Charles S. Semiótica. 4. ed. São Paulo: Perspectiva, 2008.

RIBEIRO, Renato J. Memórias de si, ou... Estudos Históricos, Rio de Janeiro, v. 11, n. 21, 1998. 
SANTOS, Vanderlei B. Gestão de arquivos pessoais. Aquivística.net, v. 4, n. 1, 2008 Disponível em: http://www.arquivistica. net/ojs/include/getdoc.php? $i d=480 \&$ article=131\&mode=pdf $>$. Acesso em: 11/11/2009.

SCHAEFFER, Jean-Marie. A imagem precária: sobre o dispositivo fotográfico. Campinas: Papirus, 1996. (Campo Imagético).

SHATFORD, Sara. Analyzing the subject of a picture: a theoretical approach, in Cataloging and Classification Quarterly, New York, v. 6, n. 3, p. 39-62, 1986.

SHATFORD LAYNE, Sara. Some issues in the indexing of images, in Journal of the American Society for Information Science, v. 45, n. 8, p. 583-588, 1994.

SIMIONATO, Ana Carolina. Catalogação de imagens digitais. Revista de Iniciação Científica da FFC, v. 9, n. 2, p. 116-129, 2009.

SMIT, Johanna W. A representação da imagem, in Informare - Caderno do Programa de Pós-Graduação em Ciência da Informação, Rio de Janeiro, v. 2, n. 2, p. 28-36, jul./dez. 1996.

WRIGHT, Joe. Pride and prejudice (Orgulho e preconceito). França, Estados Unidos, Inglaterra, 2005. (Filme). 


\section{Glossário}

Facebook - Website de relacionamento social

Flickr - Site da web de hospedagem e compartilhamento de imagens fotográficas, também definido como rede social.

Orkut - rede social filiada ao Google, com o objetivo de aproximar as pessoas a fazer amizades e a manter relacionamentos

Picasa - Programa de computador que permite a edição e organização de imagens fotográficas presentes no computador visando uma melhor recuperação.

Rede social - Uma das formas de representação dos relacionamentos afetivos ou profissionais dos seres entre si ou entre seus grupos de interesse, onde ocorre compartilhamento de idéias entre pessoas e/ ou grupos. 